\title{
Medialny obraz terroryzmu - projekt badania i wyniki badań pilotażowych
}

\author{
Jeśli ktoś wygląda jak terrorysta, \\ jeśli postępuje jak terrorysta, \\ jeśli chodzi jak terrorysta, \\ jeśli walczy jak terrorysta, \\ to jest terrorystą, prawda?
}

Siergiej Ławrow, „Polityka” 2016, nr 1

\section{Wstęp}

Dla współczesnych zmediatyzowanych społeczeństw media masowe są podstawowym źródłem wiedzy o świecie. Reprezentują one i konstruują szczególnie te obszary życia, do których jako odbiorcy nie jesteśmy w stanie dotrzeć bezpośrednio. Jednocześnie środki masowego przekazu operują logiką redukcji kompleksowości świata, co wymusza konieczność generalizacji i upraszczania rzeczywistości. W wypadku interesujących nas tu pojęć „terroryzm” i „terrorysta” przekłada się to na eksponowanie ściśle wyselekcjonowanych i charakterystycznych cech wywołujących określone skojarzenia. Kreowany obraz ma w konsekwencji pełnić konkretne funkcje komunikacyjne ${ }^{1}$. Konieczne wydaje się zatem określenie rangi problematyki terroryzmu w komunikacji medialnej oraz zbadanie sposobów, w jaki media konstruują obraz terroryzmu ${ }^{2}$. Niniejszy artykuł stanowi propozycję badania wspominanych problemów.

${ }^{1}$ M. Babecki, Funkcje epizodycznych gier internetowych $w$ procesach modelowania wirtualnego wizerunku terrorysty i terroryzmu. Analiza aspektowa, „Media - Kultura - Komunikacja Społeczna” 2013, nr 9, s. 48.

2 Problem mediatyzacji terroryzmu podejmowany był dotychczas przez wielu badaczy. Bazowały one jednak na odmiennych od prezentowanych w niniejszym artykule koncepcjach teoretycznych. To- 
Jako punkt wyjścia przyjęto dwa założenia: (1) terroryzm traktowany jest jako wydarzenie komunikacyjne oraz (2) media postrzegane są jako kluczowy element konstrukcji rzeczywistości. Przez ostanie piętnaście lat wszelkie akty terroru, dzięki medialnemu zapośredniczeniu, stawały się bowiem wydarzeniami medialnymi, które reprodukowane w dyskursie medialnym ulegały tradycjonalizacji, zakotwiczeniu w systemie kultury, stając się w konsekwencji tłem dla opisów innych zamachów terrorystycznych. $\mathrm{Na}$ gruncie komunikacji mamy zatem do czynienia $\mathrm{z}$, ,wydarzeniami komunikacyjnymi”, wytwarzającymi różnorodne obrazy rzeczywistości (konstrukty), które następnie - poprzez uczestnictwo w rozmaitych dyskursach - stają się częścią kolejnych konstruktów. W ten sposób dokonywany jest transfer semantyczny z jednego konstruktu wydarzeń na inny, co w konsekwencji tworzy usieciowione i współzależne związki ${ }^{3}$. Podstaw tego procesu można doszukiwać się w tezie Niklasa Luhmanna, stanowiącej, iż wszystko, co wiemy o społeczeństwie, czy też świecie w ogóle, wiemy z mass mediów ${ }^{4}$.

Pojęcie terroryzmu w ciągu ostatnich lat uległo redefinicji, a jego pole znaczeniowe $\mathrm{z}$ każdym kolejnym rokiem staje się coraz szersze. Przypisywane mu są w dodatku wyznaczniki i wymiary, które jeszcze kilkadziesiąt lat temu nie były dla niego znamienne. Co ciekawe, razem z poszerzaniem pola znaczeniowego pojęcia „terroryzm” zawęża się znaczenie pojęcia „terrorysta”. Z badań przeprowadzonych w latach 2008-2016, w których zapytano respondentów o to, kim jest terrorysta, z jakich przyczyn podejmuje swoje działania i do czego zmierza, wynika, że z każdym kolejnym rokiem obraz terrorysty staje się bardziej jednowymiarowy - ograniczony do aspektów religijnych. Terroryzm został pozbawiony (przez respondentów) podstawowych atrybutów charakterystycznych dla niego w latach 70. czy 80. (np. porywania polityków) na rzecz całkowicie nowych (np. wjeżdżanie w tłum rozpędzonym samochodem) ${ }^{5}$. Nawiązując do zamachów w Nowym Jorku, elementy konstruktu, dla którego przyjmijmy konwencjonalną nazwę

masz Goban-Klas w książce Media i terroryści (Kraków 2009) przedstawił zbliżoną do przyjętej przez autorkę tezę o relacji łączącej terroryzm z mediami. Kolejnym kompleksowym opracowaniem jest zbiór pod redakcją Des Freedman i Dai Kishan Thussu (Media and Terrorism: Global Perspectives, Los Angeles 2012), w którym przedstawione zostały zarówno teoretyczne rozważania na temat medialnej symbiozy mediów i terroryzmu, jak i wyniki badań empirycznych przeprowadzonych w różnych częściach świata. Najbardziej zbliżonym do proponowanego zakresu opracowaniem jest pozycja Media, Terrorism and Theory: A Reader Anandama P. Kavooriego i Todda Fraley’a (Lanham 2006). Odnaleźć można także liczne publikacje analizujące medialne narracje dotyczące konkretnych wydarzeń o charakterze terrorystycznym w różnych częściach świata - zob. np. B. McNair, UK media coverage of September 11, [w:] How the World's News Media Reacted to 9/11, red. T. Pludowski, Spokane 2007, s. 30-39; G. Baiocchi, Media coverage of 9/11 in Brazil, „Television \& New Media” 3, maj 2002, s. 183-189; C.F. Mobo Gao, M. Liang, Chinese print media coverage of 9/11 since 2001, „Journal of Media Sociology” 2, 2010, nr 1-4, s. 186-205; K.A. Powell, Framing Islam: An analysis of U.S. media coverage of terrorism since 9/11, „Communictaion Studies" 62, 2011, nr 1, s. 90-112.

3 M. Fleischer, Ogólna teoria komunikacji, Wrocław 2007, s. 292-295.

${ }^{4}$ N. Luhmann, Realność mediów masowych, przeł. J. Barbacka, Wrocław 2009, s. 7.

${ }^{5}$ Zob. K. Lachowska, Kim jest terrorysta? Sposoby stereotypizacji terrorystów. Analiza porównawcza wyników badań ankietowych, [w:] Badanie i projektowanie komunikacji, red. A. Siemes, M. Grech, t. 4, Wrocław 2015, s. 53-81. 
„11 września 2001”, widoczne są w wielu różnych, niejednokrotnie odległych tematycznie konstruktach wydarzeń. Wystarczy wspomnieć niektóre z nich: „wojna z terroryzmem”, „,bezpieczeństwo narodowe/światowe”, „ograniczenia praw człowieka”, „,ograniczenia i restrykcje w zakresie swobody przemieszczania się", w których bez problemu można odnaleźć referencje do tego konstruktu. Można zauważyć, że wykorzystywany sposób medialnej narracji w komunikatach dotyczących terroryzmu niewiele zmieniał się od zamachów na WTC. Koncentracja mediów na atakach terrorystycznych islamskich fundamentalistów sprawiła, iż w latach 2001-2012 wszelkie zamachy od razu przypisywane były Al-Kaidzie, natomiast teraz - niejako automatycznie - przypisywane są Państwu Islamskiemu (ISIS, PI). Aktualnie pojawiły się nie tylko nowe konteksty dla komunikacji o „terroryzmie” (wojna w Syrii, uchodźcy, kryzys imigracyjny), lecz także nowe sposoby działania terrorystów w Europie (indywidualne zamachy) oraz nowe organizacje i formy ich funkcjonowania (ISIS). W konsekwencji terroryści z ISIS w medialnej narracji zastąpili terrorystów z Al-Kaidy. Elementy te czynią terroryzm jeszcze trudniejszym do zdefiniowania/zidentyfikowania, a media - jako główne źródło wiedzy o terroryzmie - stanęły przed istotnym zadaniem - definiowania tego, co jest dziś terroryzmem, a co nim nie jest.

Trudności te zobrazuję przykładami z ostatnich miesięcy. 18 maja 2017 r. były żołnierz amerykańskiej marynarki wojennej Richard Rojas z dużą prędkością wjechał w tłum ludzi na Times Square w Nowym Jorku. W wyniku tego zdarzenia zginęła jedna osoba, a dwadzieścia dwie zostały ranne. Po zatrzymaniu Rojas powiedział policjantom: „Chciałem zabić ich wszystkich”. Policja wykluczyła, jakoby incydent miał charakter terrorystyczny ${ }^{6}$. Kolejne zdarzenie, o zbliżonym scenariuszu, zostało już jednakże sklasyfikowane jako zamach terrorystyczny. 22 marca 2017 r. na Moście Westminsterskim w Londynie Khalid Masood wjechał rozpędzonym samochodem w tłum ludzi, a następnie zaatakował nożem policjanta. W wyniku jego działań zginęło sześć osób, a czterdzieści dziewięć zostało rannych. Pierwsze komunikaty pojawiające się w mediach wskazywały na zamach terrorystyczny „inspirowany propagandą Państwa Islamskiego". Policja prowadząca śledztwo w sprawie ataku nie znalazła jednak bezpośrednich powiązań z grupami terrorystycznymi. Do zamachu przyznało się ISIS, nazywając Masooda „żołnierzem Państwa Islamskiego”7.

Te przykłady obrazują płynną granicę między przestępstwem kryminalnym a zamachem terrorystycznym. Jednocześnie wskazują religię jako podstawowy motywator terroryzmu ostatnich lat. Pojawiają się zatem pytania: jacy aktorzy medialni/ polityczni odpowiadają za definiowanie terroryzmu?, jakie warunki muszą spełniać działania, aby zostały zakwalifikowane jako akt terrorystyczny? Czy za wyznaczni-

6 Times Square crash: Man charged said he wanted to „kill them all”, 2017, https://www.theguardian. com/us-news/2017/may/19/times-square-crash-man-charged-murder (dostęp: 10.06.2017).

7 T. Batchelor, Khalid Masood: London attacker had no links to Isis or al-Qaeda, says Met Police, 2017, http://www.independent.co.uk/news/uk/home-news/khalid-masood-london-attack-isis-al-qaeda-nolinks-police-a7652696.html (dostęp: 20.06.2017). 
ki różnicujące klasyfikację działań można przyjąć pochodzenie, rasę, religię, czy też definiowanie terroryzmu odbywa się na bazie opozycji „my-oni”, „swój-obcy”, jak obrazują to podane przykłady?

\section{Problemy definicyjne terroryzmu}

Stawiając $w$ centrum zainteresowań sposoby definiowania i przedstawiania terroryzmu w mediach, należy zarysować kwestię złożoności zjawiska i problemów, z których wynika tak trudna jego identyfikacja. Brak jednoznacznej, akceptowalnej na arenie międzynarodowej definicji czyni z terroryzmu pojęcie o negocjowalnych granicach, ulegające ciągłej redefinicji w zależności od aktualnych wydarzeń, polityki czy podmiotów te definicje stosujących. Wielowymiarowość terroryzmu przyczyniła się do wypracowania na arenie międzynarodowej ponad sto definicji, koncentrujących się na jego różnych elementach i aspektach. Według specjalistów od terroryzmu międzynarodowego jednoznaczne zdefiniowanie zjawiska jest praktycznie niemożliwe, gdyż termin ten jest zbyt obszerny ${ }^{8}$. Problemy definicyjne pojawiają się na kilku płaszczyznach ${ }^{9}$. Czasami trudno odróżnić terroryzm od zjawisk pokrewnych, noszących znamiona działalności terrorystycznej, wykorzystujących metody stosowane przez terrorystów, a jednak funkcjonujących w przestrzeni społecznej (a także na poziomie lingwistycznym) jako odrębne pojęcia, np. „walka narodowowyzwoleńcza”, „działania partyzanckie/rewolucyjne”.

Należy zatem zastanowić się, co jest aktem terrorystycznym. Tak samo ważna jest odpowiedź na pytanie, kto jest terrorystą. Mowa tu nie tylko o słownikowej definicji, ale też o warstwie semantycznej pojęcia. Mamy bowiem do czynienia z odmiennymi asocjacjami w wypadku terminów wchodzących w zakres definicyjny terroryzmu. Zupełnie odmienną semantykę i wartościowanie posiadają takie pojęcia, jak „partyzanci”, „bojownicy o wolność”, „islamiści”, „dżihadyści” czy „separatyści”. Można zatem założyć, że kontekst determinuje użycie danego określenia, co w konsekwencji przyczynia się do odmiennej semantyzacji i wartościowania. Innym problemem jest odróżnienie terroryzmu od zwykłych przestępstw kryminalnych (patrz przykład przytoczony we wstępie). Metody wykorzystywane przez terrorystów/bojowników stosowane są bowiem niejednokrotnie przez grupy i organizacje niebędące ugrupowaniami terrorystycznymi, np. anarchistów, ekologów lub grupy przestępcze.

Kolejnym elementem stanowiącym o złożonej formie zjawiska są jego przyczyny i cele. Nie sposób odzwierciedlić w kilku zdaniach definicji tak zróżnicowanych moty-

${ }^{8}$ Zob. np. S. Wojciechowski, Terroryzm - analiza pojęcia, „Przegląd Bezpieczeństwa Wewnętrznego" 2009, nr 1, s. 54-60.

${ }^{9}$ Szerzej zob. D. Casale, Institutional and legal aspects of UE counter-terrorism, „Legal Aspects Combating of Terrorism" 47, 2008, s. 115-129. 
wacji terrorystów. Jednak chcąc odróżnić terroryzm od zwykłego przestępstwa, należy ulokować go w określonym kontekście (ideologicznym, religijnym, politycznym itp.), który jest źródłem impulsów do pewnych działań i z którego często wynikają cele zamachowców. Na tym poziomie należy zastanowić się, czy istnieje usprawiedliwienie dla działań terrorystów. Część krajów rozwiniętych dążyła do uznania (na arenie międzynarodowej) metod wykorzystywanych przez terrorystów za przestępstwa kryminalne, niezależnie od motywów. Natomiast inne państwa (np. afrykańskie, azjatyckie) chciały usprawiedliwienia części działań terrorystów w myśl prawa do samostanowienia narodów, w tym walk narodowowyzwoleńczych ${ }^{10}$. Trudności definicyjne potęgowane są również faktem, że część państw popiera terroryzm jako formę polityki, wykorzystuje jego narzędzia w polityce wewnętrznej oraz wspiera organizacje terrorystyczne.

Należy też pamiętać, że terroryzm jest zjawiskiem dynamicznym, ewoluującym w czasie, które zmienia się nie tylko na poziomie przyczyn i celów wyznaczanych przez organizacje, lecz także rozwija się pod względem technologicznym, czego przykładami są cyberterroryzm czy bioterroryzm.

Wskazane czynniki to jedynie niektóre z elementów czyniących zjawisko terroryzmu trudnym do zdefiniowania. Należy wziąć też pod uwagę różnorodność organizacji, przyczyn i celów samych zamachowców. Powoduje to, iż niemal niemożliwe staje się zawarcie w kilku słowach definicji tak odmiennych elementów, czasami nawet $\mathrm{z}$ sobą sprzecznych. W końcu definicje stanowiące o dzisiejszym wymiarze terroryzmu niekoniecznie będą adekwatne w stosunku do działań sprzed lat ${ }^{11}$.

W celu ukazania złożoności badanego zjawiska postanowiono zaprezentować przykłady definicji, różnicując je pod względem podmiotów je tworzących i stosujących. Większość definicji funkcjonujących w Polsce przedstawia terroryzm jako formę buntu pojedynczych jednostek lub grup przeciwko określonemu porządkowi politycznemu i społecznemu, za którym stoi państwo i prawo ${ }^{12}$. Natomiast Stany Zjednoczone w ramach swoich struktur wypracowały kilka oficjalnych definicji zjawiska - co ciekawe, funkcjonujących w niezmienionej formie od $2013 \mathrm{r}$. Według nich terroryzm to:

CIA: zaplanowane, motywowane politycznie użycie przemocy wobec celów niewalczących, stosowane przez subnarodowe grupy lub tajnych agentów ${ }^{13}$;

${ }^{10}$ M. Madej, Międzynarodowy terroryzm polityczny, Warszawa 2001, s. 65.

11 Zob. D. Casale, op. cit.; L. Weinberg, A. Pedahzur, S. Hirsch-Hoefler, The challenges of conceptualizing terrorism, „Terrorism and Political Violence” 16, 2004, z. 4, s. 777-794.

12 Zob. Terroryzm, [hasło w:] Słownik języka polskiego PWN, 2017, https://sjp.pwn.pl/sjp/terroryzm;2578078.html (dostęp: 26.06.2017).

${ }^{13}$ Central Intelligence Agency, Terrorism FAQs, 2017, https://www.cia.gov/news-information/cia-the-war-on-terrorism/terrorism-faqs.html (dostęp: 26.06.2017). Tłumaczenie K.L. — jeśli nie zaznaczono inaczej, wszelkie tłumaczenia zostały dokonane przez autorkę. W wypadku przekładów z języka arabskiego współpracowano z Centrum Tłumaczeń z Włocławka. 
FBI: bezprawne użycie siły lub przemocy wobec ludzi lub mienia, celem zastraszenia lub wywarcia przymusu na rząd, ludność cywilną lub części z nich, dążące do osiągnięcia celów politycznych i społecznych ${ }^{14}$;

Departament Obrony Stanów Zjednoczonych: zamierzone użycie bezprawnej przemocy (lub groźba jej użycia), mające wywołać poczucie zagrożenia, dążące do zastraszenia rządu lub społeczeństwa, w celu osiągnięcia celów politycznych, religijnych lub ideologicznych ${ }^{15}$.

Po zamachu na World Trade Center 11 września 2001 r. w ramach prac przedstawicieli państw należących do Unii Europejskiej została stworzona definicja terroryzmu akceptowalna przez piętnaście krajów (była to pierwsza prawna definicja uznana przez tak dużą liczbę państw) ${ }^{16}$. Ponowne prace zostały podjęte w $2002 \mathrm{r}$. Miały one na celu dokładniejsze określenie działań mających znamiona terroryzmu i wyzbycie się politycznego wymiaru w jego definiowaniu ${ }^{17}$. Przyjęta definicja to najobszerniejsza stosowana dotychczas na arenie międzynarodowej formuła - jest to tzw. definicja step-by-step ${ }^{18}$. Wyszczególniono w niej wskaźniki terroryzmu, zdefiniowano pojęcie grupy terrorystycznej oraz sprecyzowano zasady postępowania w stosunku do terrorystów ${ }^{19}$.

Warto też zwrócić uwagę na sposób definiowania zjawiska przez media amerykańskie. Według „The New York Times” „wojna konwencjonalna ma na celu zdobycie terytoriów i miast, podczas gdy terroryzm pragnie wyrządzić szkody kilku osobom po to, by zastraszyć tysiące" 20 . Istotny jest również sposób pojmowania terroryzmu przez instytucje międzynarodowe: ONZ, Unię Europejską i Europol.

W raportach przedstawianych przez Europol działania terrorystyczne określane są jako

umyślne akty, które ze względu na swój charakter lub kontekst mogą wyrządzić poważne szkody krajowi lub organizacji międzynarodowej, gdy zostały popełnione w celu poważnego zastraszania ludności lub bezprawnego zmuszenia rządu lub organizacji międzynarodowej do podjęcia lub zaniechania działania,

${ }^{14}$ Federal Bureau of Investigation, What we investigate, 2017, https://www.fbi.gov/stats-services/ publications/terrorism-2002-2005 (dostęp: 26.06.2017).

${ }^{15}$ International Terrorism and Security Research, What is terrorism, 2017, http://www.terrorismresearch.com/ (dostęp: 26.06.2017).

${ }^{16}$ K. Kubiak, Wojna asymetryczna i terroryzm jako zagrożenie bezpieczeństwa państwa, [w:] Bezpieczne niebo: konferencja naukowa, Warszawa, 10 września 2002, red. A. Doraczyńska, D. Strasburger, Warszawa 2002, s. 109.

17 Zob. D. Casale, op. cit.

${ }^{18} \mathrm{~K}$. Liedel, Zwalczanie terroryzmu międzynarodowego w polskiej polityce bezpieczeństwa, Warszawa 2010, s. 24.

19 Zob. Decyzja ramowa Rady Europejskiej z dnia 13 czerwca 2002 r. w sprawie zwalczania terroryzmu (2002/475/WSiSW), s. 19, http://eurlex.europa.eu/LexUriServ/LexUriServ.do?uri=DD:19:06:32002F0475:PL:PDF (dostęp: 6.03.2013). Przepisy zostały uzupełnione i dostosowane do aktualnej sytuacji w Europie w 2008 r. - Decyzja ramowa Rady Europejskiej z dnia 28 listopada 2008 r. w sprawie zwalczania terroryzmu (2008/919/JHA), http://eur-lex.europa.eu/legal-content/ EN/TXT/?uri=celex:32008F0919 (dostęp: 20.07.2017).

${ }^{20}$ L.A. Villamarin Pulido, Sieć Al-Kaida, przeł. D. Zasada, Warszawa 2008, s. 30. 
lub w celu poważniej destabilizacji lub niszczenia podstawowych struktur politycznych, konstytucyjnych, ekonomicznych lub społecznych kraju lub organizacji międzynarodowej ${ }^{21}$.

Natomiast Rada Bezpieczeństwa ONZ w 2004 r. zaproponowała następującą definicję terroryzmu:

[Terroryzm to - K.L.] wszelkie działania prowadzące do śmierci lub poważnych uszkodzeń ciała ludności cywilnej albo innych osób niebiorących czynnego udziału w działaniach wojennych, kiedy celem takiego czynu, wynikającym ze swej natury i kontekstu, jest zastraszenie ludności lub zmuszenie rządu albo organizacji międzynarodowej do wykonania bądź powstrzymania się od wykonania jakiegoś czynu $^{22}$.

Przedstawione definicje prezentują punkt widzenia szeroko pojętego Zachodu: obserwatorów, instytucji, naukowców, mediów. Warto jednak zwrócić uwagę również na sposób, w jaki osoby powszechnie uważane za terrorystów definiują terroryzm.

Osama bin Laden (były przywódca Al-Kaidy) stworzył własną definicję, którą przedstawił podczas wywiadu telewizyjnego w 1998 r.:

Ograbiają nas z naszego bogactwa, naszych zasobów naturalnych i ropy. Nasza religia jest pod ostrzałem krytyki. Zabijają i mordują naszych braci. Narażają na szwank nasz honor i godność, a gdy ośmielimy się wypowiedzieć choć słowo protestu przeciwko tej niesprawiedliwości, jesteśmy nazywani terrorystami ${ }^{23}$.

Jaser Arafat (przewodniczący OWP, założyciel Al-Fatah) podczas Zgromadzenia Ogólnego ONZ w 1974 r. przekonywał natomiast, że:

Różnica między rewolucjonistami a terrorystami leży w sprawie, o którą walczą. Nikt, kto walczy o słuszną sprawę oraz o wolność i niepodległość swojej ziemi, nie może zostać nazwany terrorystą ${ }^{24}$.

Po zamachach dokonanych przez Al-Kaidę (w szczególności w USA, Anglii, Hiszpanii) oraz ISIS (w Belgii, Francji) pojęcie terroryzmu zostało w dużej mierze zredukowane do terroryzmu religijnego, a w szczególności islamskiego. Przyjęto zatem za poznawczo istotne zaprezentowanie sposobu definiowania terroryzmu przez muzułmańskiego duchownego wyższej rangi, pochodzącego z Arabii Saudyjskiej, według którego terroryzm to

akt powodujący poczucie strachu i niebezpieczeństwa; zastraszenie ludzi z wykorzystaniem przemocy; celowe i systematyczne użycie wszelkich środków do stworzenia stanu terroru w celu osiągnięcia okre-

21 Europol, TE-SAT: Terrorism situation and trend raport 2017, 2017, s. 54, https://www.europol. europa.eu/activities-services/main-reports/eu-terrorism-situation-and-trend-report-te-sat-2017 (dostęp: 15.09.2017).

22 United Nations, A More Secure World: Our Shared Responsibility. High-Level Panel on Threats, Challenges and Change, 2004, s. 52, http://www.un.org/en/peacebuilding/pdf/historical/hlp_more_secure_ world.pdf (dostęp: 29.09.2017).

23 Cyt. za: P. Rees, Kolacja z terrorystą. Spotkania z najbardziej poszukiwanymi bojownikami na świecie, przeł. B. Dąbrowa-Kość, G. Kość, Kraków 2008, s. 38.

24 Cyt. za: B. Hoffman, Oblicza terroryzmu, przeł. H. Pawlikowska, Warszawa 2001, s. 24. 
ślonych celów; haniebny akt barbarzyństwa; akt sprzeczny ze społeczną moralnością, będący pogwałceniem ludzkiej godności ${ }^{25}$.

Przytoczone definicje są jedynie przykładem, wybranym spośród wielu dostępnych w literaturze. Wybór ten nie był jednak przypadkowy — zaprezentowano charakterystykę zjawiska przy jednoczesnym uwzględnieniu szerokiej perspektywy, która wynika $\mathrm{z}$ funkcjonalności samych definicji, rozumianych tu jako interpretacja zjawiska przez dany podmiot w konkretnym celu (np. FBI — ściganie terrorystów). Definicje te mają charakter intersubiektywny, porządkujący wiedzę o świecie i pełniący funkcje w obrębie danego systemu (np. religia, społeczeństwo).

\section{Mediatyzacja terroryzmu}

Zamachy z 11 września 2001 r. były punktem przełomowym w globalnym dyskursie o terroryzmie. Ich medialność sprawiła, że stały się wydarzeniem kulturowym, do którego ograniczały, a następnie odwoływały się wszelkie przekazy medialne. Sposób narracji medialnego dyskursu o terroryzmie sprawil, iż zjawisko posiadające dotychczas różnorodne oblicza, odmienne źródła i korzenie oraz skoncentrowane na wielu, czasem sprzecznych, żądaniach zostało sprowadzone do terroryzmu islamskiego. To właśnie on stanowi punkt centralny w sposobach mówienia i pokazywania terroryzmu.

Pomimo upływu czasu, licznych zamachów terrorystycznych, zarówno o podłożu religijnym, jak i politycznym, nadal można odnotować nawiązania do WTC, np. po zamachach w Bostonie (w 2013 r.), kiedy w mediach pojawiały się komentarze typu: „to najtragiczniejszy zamach w USA od czasów zamachów z 11 września”" ${ }^{26}$. W ciągu ostatnich lat wzmożona aktywność grup terrorystycznych powiązanych z Państwem Islamskim w Syrii, Turcji, Libanie czy Iraku przełożyła się na dużą liczbę (ciągłość) komunikatów dotyczących terroryzmu pojawiających się w mediach, a co za tym idzie generowanie poczucia lęku przed potencjalnym zamachem. Mnogość informacji dotyczących działań PI sprawia, iż doniesienia o atakach dokonywanych przez grupy inne niż islamskie nie mają szansy przebicia się/zapamiętania. W konsekwencji społeczny obraz terrorysty stanowi bezpośrednie przełożenie jego wizerunku kreowanego przez media, a tym samym wytwarzany jest jednowymiarowy obraz zjawiska (stereotyp). Mediatyzacja rozumiana jest tu zatem jako proces wzajemnego oddziaływania między

${ }^{25}$ S.H. bin Shuaibi Okla, Znaczenie terroryzmu i rzeczywistości, 2001, http://www.saaid.net/Warathah/hmood/h42.htm (dostęp: 6.03.2013).

${ }^{26}$ Dżochar Carnajew uznany za winnego zamachu $w$ Bostonie, 2017, https://wiadomosci.wp.pl/ dzochar-carnajew-uznany-za-winnego-zamachu-w-bostonie-6025268084437633a (dostęp 26.06.2017). 
mediami a społeczeństwem ${ }^{27}$ i definiowana jako wpływ mediów, poprzez formę obrazowania rzeczywistości, na ostateczny sposób jej postrzegania przez odbiorców ${ }^{28}$.

Za punkt wyjścia niniejszych rozważań przyjęto teorię Niklasa Luhmanna z jego centralną tezą, iż wszystko, co wiemy na temat świata, wiemy z mediów masowych ${ }^{29}$. Media masowe definiowane są jako wszystkie urządzenia, które wykorzystują techniczne środki powielania do rozpowszechniania komunikacji. Innymi słowy, są to te narzędzia komunikacji, które opierają się na braku interakcji między nadawcą a odbiorcą, dzięki czemu w wysokim stopniu zapewniona zostaje wolność komunikacji, a w konsekwencji wytwarzana zostaje nadwyżka możliwości komunikacyjnych, „która kontrolowana może być tylko wewnątrzsystemowo przez samoorganizację i przez własne konstrukcje realności”30. Luhmann jednocześnie podkreśla, że komunikacja medialna dochodzi do skutku jedynie wtedy, kiedy z komunikacji rozwija się komunikacja. Sama irytacja systemu (działanie powiadamiające) nie jest komunikacją - musi być ona nie tylko dostrzeżona, lecz także zrozumiana w stopniu umożliwiającym perpetuowanie komunikacji ${ }^{31}$. Mass media, poprzez to, co i jak komunikują, wpływają na proces konstrukcji rzeczywistości, wykorzystując przy tym określone selektory. Nawiązując do koncepcji Gerharda Rotha, należy wskazać, że proces postrzegania, a tym samym budowania naszej wiedzy o świecie, polega na przypisywaniu znaczeń procesom neuronalnym (które, co do zasady, są pozbawione znaczenia) na podstawie wcześniejszych doświadczeńn ${ }^{32}$.

Podstawowym kodem komunikacji mediów masowych jest „informacja” i „nieinformacja” - pierwszy element umożliwia systemowi działanie. Pojęcie „informacji” definiowane jest w odniesieniu do koncepcji Gregory’ego Batesona, czyli jest ,jakąkolwiek różnicą, która w późniejszym wydarzeniu czyni różnicę" ${ }^{33}$. Jednocześnie, jak podkreśla Luhmann, „nie każda różnica czyni różnicę”. System operuje w ogromnej ilości danych, wobec czego ma do czynienia z nadwyżką rozróżnień. Różnicę czynią zatem te elementy, które krótkoterminowo lub długoterminowo pozostają w pamięci ${ }^{34}$. Ważnym elementem jest także czas, który z informacji czyni nieinformację. Informacje są niepowtarzalne, raz zakomunikowane stają się nieinformacją. Nieinformacja jest równocześnie istotnym elementem mediów masowych. Tracąc status informacji, nie traci swojej wartości, przez

27 W. Schulz, Politische Kommunication, Wiesbaden 2008, s. 324.

28 A. Szymańska, A. Hess, Mniejszości narodowe, etniczne i religijne w przekazie mediów. Metodologia międzynarodowych badań porównawczych, Kraków 2014, s. 12.

${ }^{29}$ N. Luhmann, op. cit, s. 7.

${ }^{30}$ Ibidem, s. 8.

${ }^{31}$ Ibidem, s. 9.

32 Zob. M. Fleischer, Media w perspektywie konstruktywizmu, „2K - Kultura i Komunikacja” 2005, nr 1-2, s. 18.

33 G. Bateson, Ökologie des Geistes: Anthropologische, psychologische, biologische und epistemologische Perspektiven, Frankfurt 1981, s. 488, cyt. za: N. Luhmann, op. cit., s. 25.

${ }^{34}$ N. Luhmann, op. cit., s. 25. 
co w dalszym ciągu jest reprodukowana w mediach. Mechanizm powtarzania doskonale widoczny jest chociażby w reklamie. Przetwarzanie informacji w nieinformacje wymusza jednocześnie na systemie konieczność pozyskiwania nowej informacji ${ }^{35}$.

Proces produkcji mediów opiera się zatem na autopoietycznej i samofererencyjnej zasadzie nowości. „Nowość” jest wytworem mediów, które selekcjonując doniesienia, decydują, co jest nowe, a więc „co ma zawierać informację, czyli co właśnie jest wytwarzane, ponieważ jest to wytwarzane" ${ }^{36}$. Komunikacja mediów masowych nie jest jednakże nastawiona na przekazywanie informacji, ale budowanie wiabilnych konstruktów. Komunikaty wykorzystywane są zatem do „dopasowania, przystosowania, sprawdzania i negocjowalności intersubiektywnych konstruktów z uwagi na ich zgodność, pokrywanie się z innymi kolektywnymi konstruktami i ich elementami oraz obrazami świata" 37 .

Ukształtowana na podstawie przekazów medialnych społeczna konstrukcja świata, w następstwie procesów komunikacyjnych, reprodukowana jest wśród danych społeczności, przyczyniając się do kreowania nie realności rzeczywistości, a jedynie różnorodnych jej konstruktów. Media, jak podkreśla Luhmann, coraz częściej wykorzystywane są jako instrumenty tworzenia kognitywnych i komunikacyjnych konstrukcji rzeczywistości ${ }^{38}$. Oferty medialne nie są jednakże odwzorowaniem rzeczywistości, ale impulsami dla systemów kognitywnych i komunikacyjnych napędzających konstrukcje rzeczywistości pojedynczych systemów autopoietycznych. „Jeśli oferty medialne nie zostaną użyte, $[\ldots]$ nie »transportują " zupełnie niczego. Jeśli natomiast zostaną użyte, każda z nich wydarza się w sposób specyficzny dla systemu"39. Nie służą więc transportowaniu „prawdy” czy „odzwierciedlaniu rzeczywistości”, lecz ich podstawowymi kryteriami są "przydatność/użyteczność" i „wiarygodność” tworzona w oparciu o „obiektywnośc”, rozumianą jako „intersubiektywna umowa na temat sposobów konstrukcji rzeczywistości, który może być oczekiwany od dziennikarstwa” ${ }^{40}$. Każdy „pojedynczy uczestnik ma szansę wyłowić z oferty to, co mu odpowiada lub co w jego środowisku (np. polityka czy nauczyciela) uznaje się za potrzebną wiedzę" 41 .

Luhmann zauważa, że rosnące skomplikowanie świata wymusza na mediach większą selektywność, co w konsekwencji niesie zagrożenie wytwarzania zbyt prostego obrazu świata (problem ten był widoczny we wcześniejszych badaniach autorki - rekonstrukcji

35 Ibidem, s. 26.

${ }^{36}$ M. Fleischer, Konstrukcja rzeczywistości 2, Wrocław 2008.

37 M. Fleischer, Media w perspektywie..., s. 10.

38 S.J. Schmidt, Konstruktywizm jako teoria mediów, [w:] Konstruktywizm w badaniach literackich, red. E. Kuźma, A. Skrendo, J. Madejski, Kraków 2006, s. 326.

39 S.J. Schmidt, Rzeczywistość obserwatora, [w:] Radykalny konstruktywizm. Antologia, red. B. Balicki, D. Lewiński, B. Ryż, Wrocław 2010, s. 244-245.

${ }^{40}$ M. Fleischer, Media w perspektywie..., s. 13.

${ }^{41}$ N. Luhman, op. cit., s. 8-9. 
obrazu terroryzmu wśród Polaków ${ }^{42}$ ). Media wykorzystują bowiem określone selektory, dążąc do wzmocnienia, a jednocześnie uproszczenia przekazu, w celu dotarcia do możliwie szerokich kręgów odbiorców. W tym celu posługują się następującymi selektorami: zaskoczenie, rozumiane tu jako „nowa informacja”, konflikty, ilości (nawiązywanie do liczb, możliwość ukazywania wzrostów i spadków, ogromu strat itd.), odniesienia lokalne, przekraczanie norm, naruszanie prawa, oceny moralne („reprodukcja kodu moralności - różnica między dobrym i niedobrym działaniem”), wyrażanie opinii i żądanie aktualności ${ }^{43}$. Proces selekcji „,dekontekstualizuje i kondensuje” określone jednostki i tożsamości, które same w sobie nie posiadają nic „tożsamego”. Celem tego procesu jest wytworzenie nawiązywalności, albowiem jedynie to, co identyfikowalne, może być przekształcone w określony schemat i/lub skojarzone z innym schematem. Efektem ubocznym tworzenia schematów jest ich generalizacja. Z tego też względu rekonstrukcja medialnej rzeczywistości jest możliwa jedynie poprzez obserwowanie, jak media obserwują rzeczywistość ${ }^{44}$.

\section{Koncepcja badania}

Inspiracją niniejszego projektu badawczego były wyniki badań poświęconych wizerunkowi terrorysty i terroryzmu, zrealizowane wśród respondentów czterech europejskich krajów (Polska, Dania, Hiszpania i Włochy) ${ }^{45}$. Wykazały one, że niezależnie od doświadczeń związanych z działalnością terrorystyczną danego kraju respondenci kojarzyli terroryzm głównie $\mathrm{z}$ aktywnością fundamentalistów islamskich (wskazując cele i przyczyny ich działań), a terrorystę portretowali głównie jako muzułmanina z brodą. Wyobrażenia te składały się na centralną część konstruktu terroryzmu w Danii i Polsce, natomiast w Hiszpanii i we Włoszech elementy te, pomimo iż stanowiły znaczącą część wskazań, przeplatały się z czynnikami regionalnymi. Niewielu respondentów potrafiło jednak odnieść się do konkretnych zamachów dokonanych przed 11 września 2001 r. (wyjątek stanowili Hiszpanie). Zachowania mediów, sposób medialnych relacji zamachów na WTC oraz wyniki przeprowadzonych badań pozwalają twierdzić, że 11 września wszedł do systemu kultury, zakotwiczył się i uległ tradycjonalizacji, przez co ma wpływ na nowe wydarzenia, niekoniecznie bezpośrednio z nim związane. Warto zauważyć, że trudno wskazać incydent o charakterze terrorystycznym, mający miejsce w ciągu ostatnich lat, któremu media nadałyby podobną rangę.

42 K. Lachowska, Kim jest terrorysta? Sposoby stereotypizacji terrorystów. Analiza wyników badań ankietowych, [w:] Badanie i projektowanie komunikacji 4, red. M. Grech, Kraków 2015, s. 53-81; eadem, Terroryzm jako zjawisko komunikacyjne, [w:] Teorie komunikacji i mediów, red. M. Graszewicz, J. Jastrzębski, Wrocław 2010, s. 151-175.

${ }^{43}$ Zob. ibidem, s. 35-44.

${ }^{44}$ Ibidem, s. 31-50.

45 K. Lachowska, op. cit. 
Mając na uwadze przedstawione kwestie, za istotne uznano próbę określenia rangi problematyki terroryzmu w komunikacji medialnej oraz zbadanie sposobów, w jaki media definiują terroryzm. Jest to kluczowe głównie z uwagi, że w wypadku zjawisk, z którymi nie mamy bezpośredniego kontaktu, to właśnie różnorodne media (książki, prasa, telewizja) wytwarzają określone oferty medialne dostarczające różne, niejednokrotnie wykluczające się narracje, które przekładają się na konstrukcję rzeczywistości. Kolejnym problemem wartym analizy jest sprawdzenie, które wydarzenia uznawane są przez media za akty terroru oraz jak są one hierarchizowane. W końcu ostatnim polem badawczym jest rekonstrukcja medialnego obrazu terrorysty i terroryzmu, analiza sposobów stereotypizacji danych pojęć i ich zmienności w czasie oraz określenie pól semantycznych pojęć „terroryzm” i „terrorysta”.

Odpowiedzi na te pytania są o tyle istotne, że - jak wskazują doświadczenia lingwistyki kognitywnej - wykorzystywane w medialnym dyskursie słowa i pojęcia nigdy nie są neutralne semantycznie i zawierają w sobie określoną wizję świata, są nośnikami określonych wartości i/lub ideologii. Pełne zrozumienie funkcji, jaką pełnią w komunikacji konkretne struktury językowe, wymaga identyfikacji podmiotów je generujących oraz zdefiniowania roli, jaką pełnią one w publicznym dyskursie ${ }^{46}$. Chcąc zatem w sposób komplementarny zbadać wpływ mediatyzacji terroryzmu na język i semantykę jego poszczególnych elementów, niezbędne jest podejście interdyscyplinarne oraz zastosowanie wieloetapowego procesu badawczego.

W proponowanym badaniu przyjęto, że materiał badawczy stanowić będą publikacje prasowe pochodzące $\mathrm{z}$ ostatnich siedemnastu lat. Proces selekcji koncentrować się będzie na wyszukiwaniu publikacji, w których co najmniej dwukrotnie występują słowa „terroryzm” i/lub „terrorysta”. Należy jednak zaznaczyć, że teksty te nie muszą być w całości poświęcone problematyce terroryzmu, mógł on jedynie stanowić tło wydarzeń, element porównawczy etc. Kilku słów uzasadnienia wymaga skoncentrowanie się na prasie. Autorka zdaje sobie sprawę, że aktualnie dominującymi i preferowanymi przed odbiorców mediami są telewizja i media elektroniczne, jednak - jak przekonuje Winfried Schulz ${ }^{47}$ - badanie prasy jest nadal reprezentatywne dla agenda setting, gdyż prasa - mimo spadków nakładów - jest najbardziej opiniotwórcza w grupach „liderów opinii”. Badania wskazują, że stałymi prenumeratorami prasy (zarówno papierowej, jak i wydań elektronicznych) są różnego typu instytucje, organizacje polityczne i społeczne oraz politycy ${ }^{48}$. Mając na uwadze różnorodność materiału oraz instytucji je tworzących, docelowo postanowiono poddać analizie materiały opublikowane w latach 2000-2017 w następujących tytułach: „Gazeta Wyborcza”, „Rzeczpospolita”, „Polityka” i „Wprost”. Z wyselekcjonowanych tekstów zostaną stworzone korpusy tekstowe ${ }^{49}$, któ-

46 T.A. van Dijk, Discourse semantics as ideology, „Discourse \& Society” 6, 1995, nr 2, s. 259.

47 W. Schulz, Politische Kommunication, Wiesbaden 2008.

${ }^{48}$ H.M. Kepplinger, Die Demontage der Politik in der Informationsgesellschaft, Freiburg 1998.

${ }^{49}$ Korpus - zbiór tekstów, które podlegają obróbce maszynowej (więcej o badaniach korpusowych zob. T. McEnery, A. Wilson, Corpus Linguistics. An Introduction, Edinburgh 2001). Korpusy tekstowe 
re w kolejnym etapie zostaną poddane analizie z wykorzystaniem metod lingwistyki korpusowej. Za wyborem tej metody przemawia fakt, że — jak podkreśla Jadwiga Sambor $^{50}$ - analizy statystyczne pozwalają odkryć takie informacje zakodowane w języku, których nie są w stanie ujawnić nawet szczegółowe analizy jakościowe.

Ponadto w ostatnich dekadach językoznawstwo korpusowe wypracowało liczne narzędzia i procedury badawcze, wykorzystywane $\mathrm{w}$ interdyscyplinarnych projektach naukowych. Dostępne aktualnie oprogramowanie pozwala na szybką i wieloaspektową analizę dużych zbiorów tekstowych. Zaletą językoznawstwa korpusowego jest także możliwość wykorzystywania zarówno analiz statystycznych (statystyka językoznawcza), pozwalających na identyfikację najważniejszych jednostek leksykalnych charakterystycznych dla danych dyskursów, jak i możliwość prowadzenia dalszych badań o charakterze jakościowym, na podstawie otrzymanych zestawień ilościowych. Przekształcenia dokonywane na dużych zbiorach danych, jak pisze Victoria Kamasa,

pozwalają na udzielenie pełniejszej odpowiedzi na pytanie dotyczące reprezentacji na przykład imigrantów niż analiza kilku artykułów. Ponadto możliwość pracy ze stosunkowo dużym korpusem danych daje badaczowi szanse na jego bardziej zrównoważony dobór oraz pozwala zastosować złożone algorytmy wyboru tekstów. Zmniejsza to ryzyko skupienia się na badaniu tekstów, których wyborem kierowała wyłącznie intuicja ${ }^{51}$.

Za istotne w kontekście proponowanych badań należy uznać przejrzyste i powtarzalne procedury, które wykorzystane do analiz różnorodnego materiału dają możliwość porównywania otrzymanych wyników.

Proces badawczy wyglądałby następująco:

W pierwszym etapie materiał będzie gromadzony i archiwizowany przy uwzględnieniu dwóch czynników - tytułu prasowego i roku. W ten sposób powstanie kilkadziesiąt mniejszych korpusów, pozwalających zaobserwować zmienność występowania i semantyki badanych konceptów w czasie. W kolejnych etapach analizy zostaną przeprowadzone na zbiorach tekstów stworzonych ze wszystkich artykułów zamieszczonych $\mathrm{w}$ danym tytule. Zebrany materiał zostanie poddany lematyzacji, rozumianej jako sprowadzenie wszelkich form fleksyjnych wyrazu do jego formy podstawowej (przy wykorzystaniu oprogramowania Provalis Research), dzięki czemu analiza statystyczna będzie uwzględniać wszystkie formy wyselekcjonowanych leksemów. Kolejnym krokiem będzie wygenerowanie list frekwencyjnych (ang. word list, frequency list), które

mogą być tworzone na poziomie ogólnym, specjalistycznym, a także przy uwzględnieniu różnorodnych kryteriów, np. język wykorzystywany w prasie czy tematyzacja. Nie ma określonej minimalnej/maksymalnej liczby słów, która powinna znaleźć się w korpusie. Rozmiar zbioru uzależniony jest od celów badania, wykorzystanych technik analizy i dostępności materiału. Zazwyczaj oscylują one w granicach od kilkudziesięciu tysięcy do kilkuset (por. V. Kamasa, Techniki językoznawstwa korpusowego wykorzystywane w krytycznej analizie dyskursu. Przegląd, „Przegląd Socjologii Jakościowej” 10, 2014, nr 2, s. 101-104).

50 J. Sambor, Język polski w świetle statystyki, [w:] Współczesny język polski, red. J. Bartmiński, Lublin 2001, s. 504.

${ }^{51}$ V. Kamasa, op. cit., s. 111. 
umożliwią identyfikację najczęściej występujących słów w zbiorze. Dane takie generowane są przez programy służące do analizy korpusowej (np. WordSmith, Provalis Research QDA Miner), najczęściej w postaci tabeli uwzględniającej częstotliwość wystąpień wyrazu oraz jego udział procentowy w korpusie. Na tej podstawie zostanie stworzona lista leksemów, które poddane zostaną dalszej analizie (wyrazy, które występowały w korpusie więcej niż 30 razy). Kolejnym krokiem będzie wypracowanie kategorii umożliwiających tematyczną klasyfikacje leksemów. W tym celu zaadaptowane zostaną programy komunikacji autorstwa Michaela Fleischera, definiowane jako elementy produkujące poszczególne systemy funkcyjne społeczeństwa ${ }^{52}$. Z zaproponowanych czternastu programów zostaną wybrane najbardziej adekwatne do podejmowanej tematyki (jednak na etapie planowania badań należy uwzględnić możliwość modyfikacji zarówno już istniejących kategorii, jak i stworzenia dodatkowych).

Listy frekwencyjne posłużą również do identyfikacji słów kluczowych, definiowanych jako „punkty, wokół których toczone są bitwy ideologiczne" ${ }^{33}$ czy „, słowa stanowiące elementy problemów" ${ }^{54}$. Funkcjonują dwa sposoby umożliwiające identyfikację słów kluczowych. Pierwszy, charakterystyczny dla językoznawstwa korpusowego, definiuje je jako słowa, które wyróżniają się wysoką frekwencyjnością w danym korpusie. Drugi przyjmuje za wyznacznik wiedzę z zakresu podejmowanego tematu, którą posiada badacz. To on decyduje o ważności elementów i wybiera te, których występowanie i konteksty zostaną poddane dalszym analizom ${ }^{55}$. Ze względu na różnorodność zebranego materiału (pod względem formatu, gatunku) za adekwatne przyjęto drugie podejście.

Wygenerowane listy frekwencyjne będą stanowić zbiór wyjściowy, albowiem analizie zostaną poddane słowa bezpośrednio związane $\mathrm{z}$ tematyką terroryzmu. Następnie wygenerowane zostaną najczęściej występujące kolokacje, rozumiane jako częste współwystępowanie słów w tekście. Umożliwi to analizę dominujących w tekstach konceptów, a w konsekwencji rekonstrukcję znaczeń charakterystycznych dla danego dyskursu ${ }^{56}$. Otrzymane w ten sposób dane ilościowe zostaną uzupełnione analizą konkordancji, czyli „wystąpień poszukiwanego terminu w korpusie, zaprezentowaną wraz z kontekstem, w którym termin ten się pojawia" ${ }^{57}$. Należy również nadmienić, że w zależności od używanego oprogramowania mamy możliwość ustawienia długości kontekstu, w którym występuje leksem — od kilku słów do całych akapitów. Wygenerowana lista w znacznym stopniu ułatwi proces analizy jakościowej oraz da pewność, że wszystkie konteksty zostały uwzględnione, co jest istotne w wypadku dużych korpusów. W konsekwencji analiza kolokacji i konkordancji umożliwi określenie znaczeń danych leksemów oraz rekonstrukcję

52 Szerzej zob. M. Fleischer, Koncepty - elementy sterujace komunikacji, Wrocław 2008.

${ }^{53}$ M. Stubbs, Words and Phrases. Corpus Studies of Lexical Semantics, Oxford 2001, s. 188.

${ }^{54}$ V. Kamasa, op. cit., s. 105.

55 Ibidem; zob. też A. Wierzbicka, Słowa klucze. Różne języki - różne kultury, przeł. I. Duraj-Nowosielska, Warszawa 2007.

${ }^{56}$ M. Stubbs, op. cit., s. 188.

57 P. Baker, Using Corpora in Discourse Analysis, London-New York 2006, s. 71. 
pola semantycznego terminów „terroryzm” i „terrorysta”. Zarówno przyjęta metoda, jak i wybrane w jej obrębie techniki badawcze stanowią jedynie propozycję analizy podjętego zagadnienia. W badaniu pilotażowym, przedstawionym w dalszej części pracy, sprawdzona zostanie możliwość oraz zasadność wykorzystania wspomnianych procedur.

\section{Wyniki badań pilotażowych}

Na podstawie rankingów czytelnictwa tygodników opinii (pierwsze półrocze 2016 r.) do analizy w ramach badania pilotażowego zakwalifikowano publikacje z tygodnika „Polityka"58. Badanie miało na celu zweryfikowanie przyjętych założeń oraz adekwatność wykorzystania obranej metody badawczej. Najważniejszymi kryteriami doboru materiałów było uwzględnienie publikacji datowanych sprzed i po zamachach z 11 września $2001 \mathrm{r}$. oraz aktualnej sytuacji społeczno-politycznej w Europie (2015-2016, kryzys imigracyjny). W konsekwencji korpusy uwzględniają publikacje z lat 2000-2002 oraz 2015-2016. Na tej podstawie możliwe będzie zaobserwowanie, czy i co zmieniło się w sposobach mówienia o terroryzmie, określenie dominujących tematów, odnalezienie wydarzeń medialnych stanowiących referencję dla innych, niekoniecznie z nim związanych, oraz rekonstrukcja pola semantycznego wyrazu ,terroryzm”. Uwzględniając wskazane wyznaczniki, stworzono pięć korpusów tekstowych, które łącznie liczyły ok. 700 tys. wyrazów.

Przyjmując za punkt odniesienia zamachy na WTC, już na poziomie zbierania materiału dało się zauważyć znaczną różnicę w liczbie publikowanych tekstów oraz ich długości. Wśród publikacji z 2000 r. znaleziono niewiele ponad 90 publikacji spełniających kryteria doboru. Natomiast w 2001 i 2002 r. było ich już ponad 250. W związku ze znacznymi różnicami w liczbie publikowanych tekstów korpus z 2000 r. był najkrótszy - składał się ze 100 tys. wyrazów. Zbiór tekstów z 2001 r. miał 170 tys., podobnie jak korpus z $2015 \mathrm{r}$. Na tej podstawie można przypuszczać, że zainteresowanie mediów tematyką terroryzmu (nie tylko na poziomie wydarzeń aktualnych, lecz także historycznych) wzrosło po zamachach z 11 września 2001 r. Wydarzenie to, poprzez relacje $\mathrm{z}$ drugiej fazy zamachów, którą odbiorcy mogli oglądać niemal "na żywo", stało się wydarzeniem komunikacyjnym, dającym początek nowym sposobom mówienia o terroryzmie. Odbiorcy, nawiązując do selektorów Luhmanna, od tego momentu żądali/żądają ciągłości i aktualności, a media dostosowując się do rynku, generują ich coraz więcej (zapewniając nawiązywalność). Istotnym elementem $\mathrm{w}$ planowanym badaniu będzie zatem prześledzenie zmian w liczbie publikacji $\mathrm{w}$ przyjętym przedziale czasowym. Umożliwi to sprawdzenie, czy od $2001 \mathrm{r}$. liczba

\footnotetext{
58 M. Kurdupski, „Gość Niedzielny” na czele sprzedaży tygodników opinii w I pótroczu 2016. „Wprost” $z$ największym spadkiem, 2016, http://www.wirtualnemedia.pl/artykul/gosc-niedzielny-na-czele-sprzedazy-tygodnikow-opinii-w-i-polroczu-2016-wprost-z-najwiekszym-spadkiem (dostęp: 28.07.2017).
} 
publikowanych tekstów o terroryzmie jest zbliżona w poszczególnych latach, oraz pozwoli na identyfikację wydarzeń, którym media nadały podobną rangę.

Po wcześniejszej lematyzacji korpusów tekstowych wygenerowane zostały listy frekwencyjne dla każdego z nich. Przyjmując, że w procesie generowania znaczeń kluczowymi jednostkami leksykalnymi są wyrazy pełnoznaczeniowe, a szczególną rolę pełnią rzeczowniki, do dalszego procesu zakwalifikowano 30 najczęściej występujących w danym korpusie rzeczowników. Ze względu na istotność włączono także nazwy własne. W otrzymanych zbiorach leksemów znalazły się grupy wyrazów o szerokim polu znaczeniowym (np. „człowiek”, „świat”), które pomimo wysokiej liczby wystąpień nie zostały uwzględnione w dalszej analizie.

Na poziomie listy frekwencyjnej (zob. tabela 1) zauważalna jest różnica zarówno pod względem występowania określnych leksemów, jak i ich hierarchizacji pomiędzy rokiem 2000 a każdym kolejnym. Pierwsza trzydziestka najpopularniejszych wyrazów w 2000 r. kończy się na 60 wystąpieniach leksemu „życie”, podczas gdy w kolejnych korpusach frekwencyjność oscyluje w okolicach 100. Przyczyn należy doszukiwać się w znacznie mniejszej objętości pierwszego korpusu, co wynika z tego, iż problematyka terroryzmu pojawiała się wówczas zdecydowanie rzadziej niż w latach kolejnych. Dysproporcja ta widoczna jest także wśród leksemów z pierwszych miejsc listy frekwencyjnej (2000 r.: „człowiek” - 173; 2001 r.: „wojna” - 511). Wśród najczęściej występujących wyrazów w 2000 r. pojawiały się słowa „władza”, „polityk”, „prezydent” i ,państwo”. Elementy te wskazują, iż w tekstach poruszane były kwestie szeroko pojętej polityki, z uwzględnieniem konkretnych państw, np. „władze Autonomii Palestyńskiej”59, „władze federalne dysponują wobec dotowanych regionów skutecznymi środkami nacisku administracyjnego i finansowego, polityka zbieżna z bliskowschodnią strategią Zachodu”. W pozostałych korpusach nawiązania do „władzy” występowały rzadziej. Warto też zwrócić uwagę, że leksem „wojna”, który w pozostałych korpusach stanowi główny koncept, w tym wypadku charakteryzował się znacznie niższą rangą.

W korpusach z lat 2001-2002 bez problemu możemy odnaleźć referencje do zamachów z 11 września - „samolot”, „wrzesień”, „bin Laden”, „Talibowie”. Dodatkowo na listach odnotowane zostały słowa „terroryzm”, „terrorysta”, „atak” i „zamach”, bezpośrednio nawiązujące do interesującej nas tematyki. W publikacjach po 2000 r. na listach frekwencyjnych pojawiają się również bezpośrednie nawiązania do islamu, który w przeprowadzonych badania ankietowych stanowił centralną część referencyjną dla konstruktu terroryzmu.

59 Wszystkie przywoływane podczas analizy cytaty i przykłady należy traktować jako część konkretnego korpusu. 


\begin{tabular}{|c|c|c|c|c|c|c|c|c|c|c|c|c|c|c|c|c|c|c|}
\hline \multirow[b]{2}{*}{$\stackrel{0}{\circ}$} & P & $\stackrel{\infty}{\sim}$ & $\stackrel{\infty}{\stackrel{\infty}{N}}$ & $\overrightarrow{\widetilde{N}}$ & $\stackrel{\hat{\sigma}}{ }$ & హ゙ & $\stackrel{\infty}{\sim}$ & $\stackrel{\infty}{\triangleq}$ & $\stackrel{\wedge}{\triangleq}$ & $\vec{\Xi}$ & $\stackrel{尺}{\bumpeq}$ & $\stackrel{尺}{I}$ & 苟 & 吾 & בे & $\stackrel{\infty}{\sim}$ & $气$ & $\Xi$ \\
\hline & 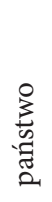 & 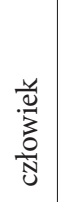 & $\begin{array}{l}\frac{\pi}{0} \\
\frac{1}{3} \\
3\end{array}$ & $\begin{array}{l}\text { مे. } \\
\text { Оे } \\
\text { ज्ञ }\end{array}$ & $\begin{array}{l}\frac{\pi}{\tilde{N}} \\
\frac{\pi}{3}\end{array}$ & 要 & 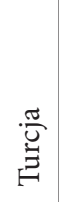 & 营 & 芯 & $\begin{array}{l}\frac{\pi}{\sqrt{0}} \\
0 \\
0\end{array}$ & 茎 & 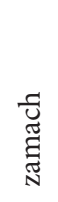 & 莺 & 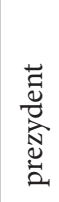 & 岕 & 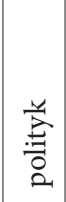 & 莺 & 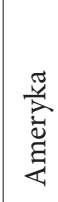 \\
\hline \multirow{2}{*}{ ఇ } & $\overrightarrow{5}$ & $\stackrel{\infty}{\text { \} }} &{\text { స్ }} &{\text { సे }} &{\text { 芯 }} &{\text { : }} &{\text { 今્ }} &{\underset{\mathbb{N}}{\mathbb{N}}} &{\underset{\sim}{\widetilde{N}}} &{\stackrel{\partial}{\sigma}} &{\text { ஓ }} &{\cong} &{\stackrel{\infty}{\circ}} &{\text { 苞 }} &{\text { 昜 }} &{\exists} &{\text { 요 }} &{\stackrel{\infty}{=}} \\
{\hline} &{\text { 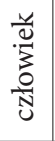 }} &{\text { 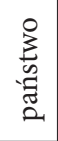 }} &{\begin{array}{l}\frac{\pi}{0} \\
\frac{3}{3} \\
3\end{array}} &{\text { 可 }} &{\frac{\frac{\pi}{\mathbb{N}}}{\frac{\pi}{3}}} &{\text { 莺 }} &{\text { 芯 }} &{\text { 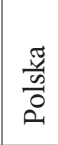 }} &{\text { 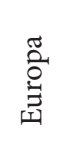 }} &{\text { 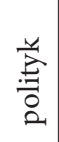 }} &{\begin{array}{l}\text { 悉 } \\
\text { 苟 }\end{array}} &{\text { 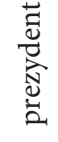 }} &{\text { 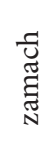 }} &{\begin{array}{l}\text { 苞 } \\
\text { 苛 }\end{array}} &{\text { 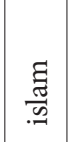 }} &{\text { 芯 }} &{\text { 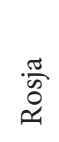 }} &{\text { 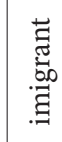 }} \\
{\hline \multirow{2}{*}{\text { ర్రి }}\text { ర్రి }} &{\underset{ల}{\infty}} &{\text { I্ }} &{\underset{\sim}{\stackrel{H}{\sim}}} &{\underset{\sim}{\mathbb{N}}} &{\widehat{\widehat{\sim}}} &{\text { సે }} &{\stackrel{\ominus}{\vec{\sim}}} &{\text { ڤેे }} &{\underset{\infty}{\infty}} &{\stackrel{\infty}{\sim}} &{\stackrel{\cong}{\bumpeq}} &{\underline{\Xi}} &{\stackrel{\bullet}{\bullet}} &{\vec{n}} &{\text { 黑 }} &{\text { I }} &{\stackrel{\infty}{\sim}} &{\text { 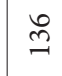 }} \\
{\hline} &{\begin{array}{l}\frac{\pi}{0} \\
\frac{0}{3}\end{array}} &{\text { 莺 }} &{\text { 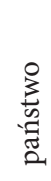 }} &{\text { 芯 }} &{\begin{array}{l}\overline{\widetilde{J}} \\
\stackrel{\mathbb{N}}{ }\end{array}} &{\text { 画 }} &{\text { 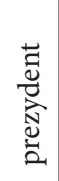 }} &{\text { 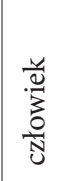 }} &{\text { 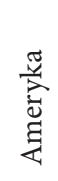 }} &{\text { 胥 }} &{\frac{u}{\grave{D}}} &{\text { 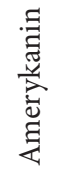 }} &{\begin{array}{l}\frac{\pi}{0} \\
\frac{\pi}{3}\end{array}} &{\text { 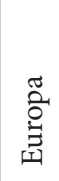 }} &{\text { 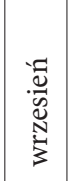 }} &{\text { 苟 }} &{\text { 苛 }} &{\text { 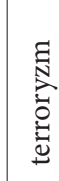 }} \\
{\hline \multirow{2}{*}{\bar{i}}\overline { i }} &{\overrightarrow{\text { n }}} &{\vec{q}} &{\underset{\infty}{+\infty}} &{\underset{\sim}{\sharp}} &{\overrightarrow{\tilde{n}}} &{\text { ఫે }} &{\underset{\sim}{\sim}} &{\stackrel{\curvearrowright}{\widehat{~}}} &{\text { 点 }} &{\text { 芯 }} &{\stackrel{\sim}{\sim}} &{\stackrel{m}{\sim}} &{\text { ڤે }} &{\stackrel{2}{\circ}} &{\text { 今 }} &{\stackrel{\infty}{\circ}} &{\stackrel{\infty}{\stackrel{\infty}{-}}} &{\text { 占 }} \\
{\hline} &{\begin{array}{l}\frac{\pi}{2} \\
\frac{3}{3}\end{array}} &{\text { 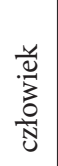 }} &{\text { 莺 }} &{\mathbb{E}} &{\text { 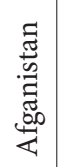 }} &{\text { 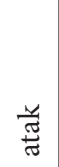 }} &{\text { 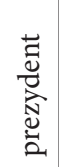 }} &{\begin{array}{l}\text { 妥 } \\
\text { 㫕 }\end{array}} &{\text { 岕 }} &{\text { 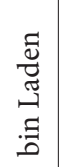 }} &{\text { 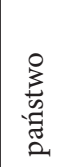 }} &{\text { 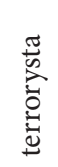 }} &{\text { 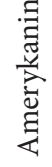 }} &{\text { 丞 }} &{\begin{array}{l}\frac{\pi}{0} \\
\tilde{c}\end{array}} &{\underset{\mathbb{N}}{\mathbb{N}}} &{\text { 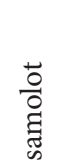 }} &{\text { 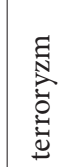 }} \\
{\hline \multirow{3}{*}{\underset{\sim}{\stackrel{్}{ }}}\underset { \sim } { \stackrel { ్ } { } }} &{\stackrel{\Omega}{=}} &{\underline{I}} &{\stackrel{\infty}{\infty}} &{\stackrel{\Omega}{6}} &{\stackrel{8}{0}} &{\text { ถે }} &{\underset{I}{I}} &{\stackrel{\leftrightarrow}{\rightarrow}} &{\Xi} &{\stackrel{m}{=}} &{\exists} &{\stackrel{\circ}{\circ}} &{\text { 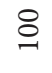 }} &{\text { 으 }} &{\infty} &{+\infty} &{\vec{\infty}} &{\text { 尺े }} \\
{\hline} &{\text { 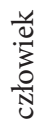 }} &{\begin{array}{l}\frac{\mathbb{N}}{\mathbb{N}} \\
\frac{\pi}{3}\end{array}} &{\text { 莺 }} &{\text { 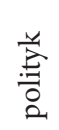 }} &{\text { 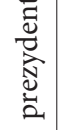 }} &{\text { 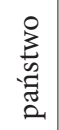 }} &{\mathbb{\Xi}} &{\text { 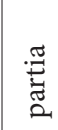 }} &{\begin{array}{l}\frac{\pi}{5} \\
0 \\
0\end{array}} &{\begin{array}{l}\frac{\pi}{0} \\
\frac{0}{3} \\
3\end{array}} &{\text { 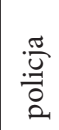 }} &{\begin{array}{l}\frac{\pi}{3} \\
\text { व }\end{array}} &{\underset{\mathbb{N}}{\mathbb{N}}} &{\text { 苛 }} &{\text { 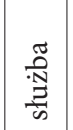 }} &{\text { 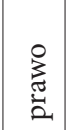 }} &{\text { 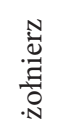 }} &{\text { 苟 }} \\
{\hline} &{\dot{-}} &{i} &{\dot{m}} &{\dot{+}} &{\text { in }} &{0^{\circ}} &{\wedge^{\circ}} &{\infty} &{\sigma^{\circ}} &{\stackrel{0}{\circ}} &{\dot{\beth}} &{\mathcal{I}} &{\dot{m}} &{\text { 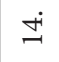 }} &{\ddot{10}} &{\stackrel{\dot{\sigma}}{\circ}} &{\text { 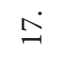 }} &{\stackrel{\infty}{\sim}} \\
$\hline
\end{tabular}




\begin{tabular}{|c|c|c|c|c|c|c|c|c|c|c|c|c|}
\hline \multirow[b]{2}{*}{$\frac{0}{2}$} & $\exists$ & อे & $\stackrel{\infty}{0}$ & 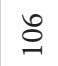 & $\stackrel{\varrho}{~}$ & ఠิ & $\overrightarrow{0}$ & $\stackrel{-}{\circ}$ & $\stackrel{-}{\circ}$ & $\stackrel{\circ}{\circ}$ & ลૂ & \\
\hline & $\begin{array}{l}\vec{Z} \\
\mathbb{Z} \\
\mathbb{Z} \\
\mathbb{N}\end{array}$ & 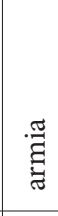 & 誊 & 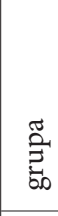 & 茎 & 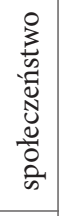 & 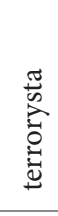 & 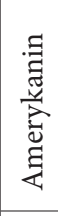 & $\begin{array}{l}\text { 咅 } \\
\text { 苛 }\end{array}$ & 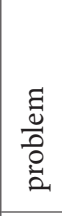 & 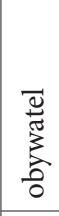 & \\
\hline & $\stackrel{\widehat{m}}{=}$ & లి & 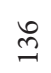 & $\stackrel{\varrho}{=}$ & $\stackrel{n}{=}$ & $\underset{\Xi}{\Xi}$ & $\cong$ & $\cong$ & $\exists$ & $\stackrel{\circ}{\exists}$ & 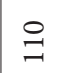 & ᄋे \\
\hline & 莺 & 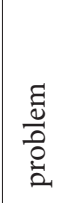 & 岕 & 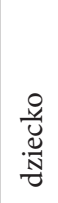 & 䔍 & 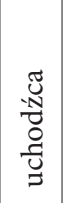 & 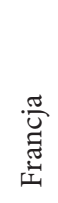 & 莺 & $\begin{array}{l}\text { 节 } \\
\text { 昙 } \\
\text { 节 }\end{array}$ & 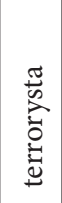 & $\begin{array}{l}\overrightarrow{0} \\
\bar{U} \\
\mathbb{J} \\
\mathbb{N}\end{array}$ & $\frac{\pi}{5}$ \\
\hline \multirow[b]{2}{*}{ రి } & $\stackrel{9}{=}$ & $\widehat{\Xi}$ & 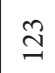 & త్ & $\stackrel{0}{=}$ & $\stackrel{m}{\exists}$ & $\stackrel{m}{=}$ & $\stackrel{m}{=}$ & $\exists$ & $\stackrel{\circ}{\exists}$ & 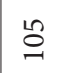 & $\stackrel{\widetilde{\sigma}}{\sigma}$ \\
\hline & 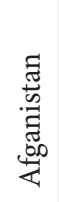 & | & $\frac{\pi}{\omega}$ & 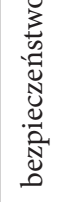 & 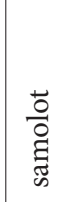 & $\begin{array}{l}\frac{\pi}{s} \\
\stackrel{2}{2}\end{array}$ & 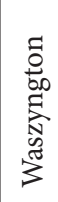 & 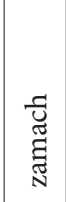 & 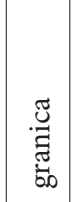 & 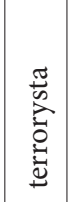 & 总 & 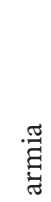 \\
\hline \multirow[b]{2}{*}{$\bar{\delta}$} & 苟 & 兽 & แ゙ & $\stackrel{\Omega}{\Omega}$ & $\tilde{n}$ & $\stackrel{\infty}{=}$ & ले & $\stackrel{\infty}{\sim}$ & $\widetilde{్}$ & $\vec{m}$ & $\vec{m}$ & $\widehat{త}$ \\
\hline & $\begin{array}{l}\frac{\pi}{0} \\
0 \\
0\end{array}$ & 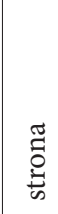 & $\begin{array}{l}\frac{\pi}{0} \\
\frac{\mathbb{\pi}}{3}\end{array}$ & 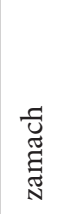 & 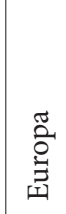 & 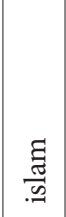 & 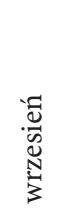 & 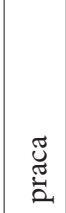 & 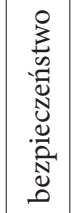 & $\begin{array}{l}\frac{\sigma}{\sqrt{n}} \\
\frac{\pi}{\sigma}\end{array}$ & 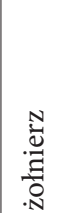 & $\frac{\pi}{\tilde{n}}$ \\
\hline \multirow{3}{*}{ ষ্ণ } & $\stackrel{\infty}{\stackrel{1}{2}}$ & $\stackrel{\infty}{\wedge}$ & $\stackrel{\text { in }}{1}$ & t & $\stackrel{\infty}{0}$ & 6 & $\hat{\sigma}$ & $\hat{\sigma}$ & 8 & ப' & 8 & $\vec{b}$ \\
\hline & 葋 & 离 & $\frac{\widetilde{g}}{\vec{\omega}}$ & 胥 & 岕 & 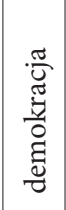 & 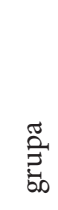 & $\begin{array}{l}\mathscr{U} \\
\text { : } \\
\text { : }\end{array}$ & 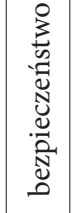 & 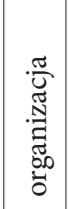 & 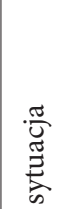 & 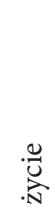 \\
\hline & $\stackrel{2}{2}$ & $\dot{\sim}$ & $\dot{\sim}$ & तi & $\ddot{\sim}$ & $\stackrel{+}{\sim}$ & வே் & $\stackrel{\dot{\nu}}{\circ}$ & $\vec{\lambda}$ & $\stackrel{\infty}{\sim}$ & จे & $\dot{m}$ \\
\hline
\end{tabular}

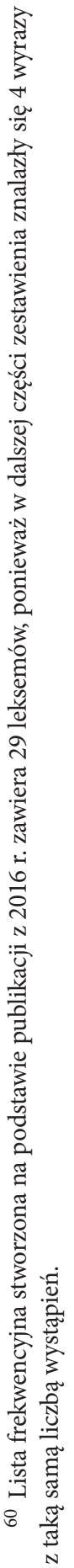


W kolejnej tabeli przedstawiono zestawienie obrazujące, które państwa najczęściej pojawiały się w publikacjach dotyczących terroryzmu. Obierając zestawienie statystyczne jako wyznacznik, dodatkowo wspomagając się analizą jakościową, na tej podstawie możemy określić konkretne konflikty oraz tematy dominujące w analizowanych tekstach. Na przykład 2000 r.: „Rosja” - konflikt w Czeczenii (w tym szkolenia saperów, uchodźcy z Czeczeni, zamachy w Czeczeni); 2000 r.: „Izrael” — konflikt izraelsko-palestyński (w tym rozmowy pokojowe w Camp David, Intifiada Al-Aksa ${ }^{61}$ ).

Tabela 2. Lista państw, do których najczęściej odnoszono się w publikacjach

\begin{tabular}{|c|c|c|l|l|l|l|l|l|l|l|}
\hline & \multicolumn{2}{|c|}{2000} & \multicolumn{2}{c|}{2001} & \multicolumn{2}{c|}{2002} & \multicolumn{2}{c|}{2015} & 2016 \\
\hline 1. & Rosja & 109 & Afganistan & 301 & USA & 244 & Polska & 224 & Turcja & 183 \\
\hline 2. & Izrael & 74 & Ameryka & 279 & Izrael & 237 & Rosja & 140 & Polska & 171 \\
\hline 3. & - & - & USA & 255 & Ameryka & 186 & Syria & 137 & USA & 129 \\
\hline 4. & - & - & Rosja & 177 & Irak & 142 & USA & 136 & Ameryka & 111 \\
\hline 5. & - & - & Polska & 154 & Afganistan & 130 & Francja & 112 & Syria & 106 \\
\hline 6. & - & - & - & - & Pakistan & 127 & Turcja & 112 & - & - \\
\hline 7. & - & - & - & - & Rosja & 113 & - & - & - & - \\
\hline
\end{tabular}

Źródło: opracowanie własne.

Komunikaty w 2001 r. zostały zdominowane przez doniesienia dotyczące zamachów na WTC, a w ich konsekwencji - wojnę wypowiedzianą przez USA terrorystom w październiku (Afganistan). Co ciekawe, ze stosunkowo wysokim współczynnikiem występowania na liście pojawiła się Polska. W tekstach jej dotyczących widoczna jest próba budowania poczucia bezpieczeństwa, np. Polska jako członek NATO, jako sojusznik USA. Pomimo zaostrzenia się w 2000 r. konfliktu w Izraelu (druga Intifiada Al-Aksa) istotne do niego nawiązania odnotowano dopiero w publikacjach z 2002 r. (w 2001 r. leksem „Izrael” nie znalazł się wśród 50 najczęściej używanych słów). W publikacjach z lat 2015-2016 znajdujemy referencje do wojny w Syrii (np. „naloty na Syrię”, „fala uchodźców z Syrii”), a także roli Rosji w tym konflikcie (np. „Rosjanie stanęli po stronie Asada”, „w Syrii jednak

${ }^{61}$ Intifiada Al-Aksa (Druga Intifiada, Wojna Arafata) — powstanie przeciwko okupacji terenów Palestyny przez Izrael. Za powód rozpoczęcia powstania przyjmuje się wizytę Ariela Szarona w Jerozolimie 28 września 2000 r. Tam też rozpoczęły się zamieszki, które rozprzestrzeniły się na Zachodni Brzeg oraz Strefę Gazy. W wyniku działań w latach 2000-2005 zginęło ponad 4000 Palestyńczyków, 1000 Izraelczyków i 63 cudzoziemców (zob. United Nations Office for the Coordination of Humanitarian Affairs, Israeli-Palestinian fatalities since 2000 - Key trends, 2007, https://unispal.un.org/DPA/DPR/unispal. nsf/0/BE07C80CDA4579468525734800500272, dostęp: 26.06.2017). Według jednych źródeł zakończenie konfliktu nastąpiło po śmierci Jasera Arafata w 2004 r., natomiast zgodnie z oficjalnymi źródłami za koniec Intifiady przyjmuje się spotkanie w Szarm el-Szejk 8 lutego 2005 r., w trakcie którego prezydent Mahmoud Abbas i premier Ariel Szaron ogłosili zawieszenie broni (zob. BBC, Full text of Abbas declaration, 2005, http://news.bbc.co.uk/1/hi/world/middle_east/4247327.stm, dostęp: 26.06.2017). 
w swoim stylu, czyli incognito, pojawili się Rosjanie”). Istotny kontekst dla leksemu „Polska” stanowi relokacja uchodźców. Z jednej strony mamy teksty, w których przedstawiane są ustalenia UE, opisywane kwoty i możliwości przyjęcia uchodźców. Z drugiej zaś pojawiają się teksty przedstawiające niechęć Polaków do przyjmowania imigrantów — wyrażana zarówno ze strony przedstawicieli niektórych partii politycznych (np. „terrorystami straszy Beata Kempa ze Zjednoczonej Prawicy”), jak i obywateli (np. „cała Polska śpiewa z nami »wypierdalać z Arabami!«”, wśród młodych Polaków - 18-34 lata - panuje przekonanie, że „Polska nie powinna przyjmować uchodźców rozumianych jako uciekinierzy z krajów objętych konfliktami zbrojnymi, zwłaszcza jeśli pochodzą z Bliskiego Wschodu i Afryki"). Nie tylko wojna w Syrii, kryzys imigracyjny, lecz także zamachy terrorystyczne stanowiły główne konteksty dla leksemu „Turcja” (np. „Turcja zaangażowała się w konflikt syryjski, [...] poza władzą stolicy są obozy szkoleniowe tzw. Państwa Islamskiego (PI) na terytorium Turcji, również w samym Stambule. Trafiają do nich młodzi ludzie spośród ponad dwumilionowej rzeszy uchodźców przybyłych z Bliskiego Wschodu"). Publikacje, w których odnotowano wystąpienia leksemu „Francja”, stanowiły analizę sytuacji państwa w kontekście dokonanych tam zamachów (np. Charlie Hebdo).

\begin{tabular}{|ll|} 
armia & walka \\
generał & wojenny \\
konflikt zbrojny & wojna \\
odwet & wojsko \\
przeciwnik & wojskowy \\
przemoc & wódz \\
służba & wróg \\
zbroić & żołnierz \\
& \\
\hline
\end{tabular}

Rysunek 1. Przykład kategorii „wojsko”

Źródło: opracowanie własne.

$\mathrm{Na}$ tej podstawie możemy wyróżnić kilka wydarzeń, wokół których koncentrowały się komunikaty dotyczące terroryzmu w danym roku (np. 2000 r. - konflikt palestyńsko-izraelski, 2015 r. - kryzys imigracyjny). Co ciekawe, jedne wydarzenia - poprzez nadanie im „ważności” - niemal całkowicie wypierały inne (np. Intifiada Al-Aksa, pomimo iż trwała od 2000 r., została wyparta przez komunikaty dotyczące WTC w 2001 r.; podobną sytuację obserwujemy w przypadku zamachów w Czeczeni). W trakcie dalszych badań należałoby sprawdzić, czy takie zachowania pojawiły się w wypadku innych zamachów. Tym samym trzeba by wskazać te, którym media nadały podobną rangę (np. w Madrycie, Londynie czy Bostonie).

Kolejnym ważnym elementem są powiązania tematyczne. $\mathrm{W}$ badaniu wstępnym udało się zauważyć, jak temat terroryzmu skorelowany jest $\mathrm{z}$ innymi wydarzeniami, aktorami i konceptami, np. terroryzm $\rightarrow$ Państwo Islamskie $\rightarrow$ zamachy w Turcji $\rightarrow$ 
wojna w Syrii $\rightarrow$ kryzys imigracyjny $\rightarrow$ plany relokacji uchodźców $\rightarrow$ bezpieczeństwo w Polsce $\rightarrow$ rasizm.

W następnym etapie badania została dokonana klasyfikacja leksemów, które pojawiły się w danym korpusie więcej niż 30 razy. Kategorie zostały stworzone na podstawie wyjściowej listy frekwencyjnej, uwzględniającej wszystkie leksemy występujące w tekście. W zestawieniu nie uwzględniono kategorii „inne”, na którą składały się wyrazy o bardzo szerokim polu znaczeniowym oraz te, których nie można było jednoznacznie sklasyfikować. Na potrzeby niniejszego badania zaadaptowane zostały programy komunikacji Fleischera, przy czym należy zaznaczyć, że część z nich została z sobą połączona; stworzono także zupełnie nowe kategorie, istotne w kontekście podejmowanej problematyki (np. religia) (zob. tabela 4). Na podstawie otrzymanych wyników możemy wskazać koncepty najczęściej wykorzystywane do mówienia o terroryzmie.

Warto zwrócić uwagę, że trzy główne kategorie („lokalizacja”, „polityka” i „,wojna"), niezależnie od długości zbioru tekstów czy wydarzeń mających miejsce w określonym czasie, są w czołówce listy rankingowej. W kategorii „religia” zostały zawarte wszystkie leksemy bezpośrednio związane z szeroko pojętym wyznaniem. Znaczna część elementów w niej uwzględnionych nawiązywała do islamu (np. 2001 r.: „islam” - 842; 2002 r.: „islam” - 563; 2015 r.: „islam” - 786, „chrześcijaństwo” - 110; 2016 r.: „islam” - 449). Należy też zaznaczyć, że istotne odniesienia do religii odnotowano dopiero w tekstach publikowanych od $2001 \mathrm{r}$. Pomimo konfliktów o podłożu religijnym, o których pisano w 2000 r. (np. w Czeczeni, Palestynie), w tekstach kładziono mniejszy nacisk na aspekt religijny niż w latach późniejszych. Kategoria „organizacje terrorystyczne" została stworzona jako zbiór referencji do działań różnych grup o tym charakterze (np. ETA, IRA). W kolejnych latach odniesienia do innych organizacji niż Al-Kaida czy Państwo Islamskie pojawiały się na tyle rzadko, że częstotliwość ich wystąpień nie przekroczyła przyjętego progu relewancji.

Tabela 3. Kategorie tematyczne leksemów

\begin{tabular}{|l|l|l|l|c|l|l|l|l|l|l|}
\hline & \multicolumn{3}{|c|}{2000} & \multicolumn{2}{c|}{2001} & \multicolumn{2}{c|}{2002} & \multicolumn{2}{c|}{2015} & \multicolumn{2}{c|}{2016} \\
\hline 1. & lokalizacja 62 & 2004 & lokalizacja & 5629 & lokalizacja & 4400 & lokalizacja & 4542 & lokalizacja & 2696 \\
\hline 2. & polityka & 1312 & wojna & 2983 & wojna & 1487 & polityka & 1795 & wojna & 1500 \\
\hline 3. & wojna & 1044 & polityka & 1331 & polityka & 1187 & wojna & 1561 & polityka & 1150 \\
\hline 4. & media & 433 & religia & 1085 & państwo & 781 & religia & 1090 & państwo & 854 \\
\hline 5. & państwo & 431 & Al-Kaida & 1001 & zamach & 596 & władza & 827 & zamach & 718 \\
\hline 6. & gospodarka & 422 & zamach & 950 & religia & 590 & państwo & 783 & władza & 494 \\
\hline 7. & władza & 404 & gospodarka & 789 & władza & 530 & zamach & 742 & religia & 488 \\
\hline 8. & $\begin{array}{l}\text { organizacje } \\
\text { terrorystyczne }\end{array}$ & 266 & państwo & 707 & prawo & 289 & gospodarka & 682 & prawo & 364 \\
\hline
\end{tabular}

${ }^{62}$ Lokalizacja rozumiana jest tu jako położenie geograficzne, leksemy zakwalifikowane do tej kategorii odnosiły się zarówno do konkretnych państw, regionów, jak i kontynentów. 


\begin{tabular}{|l|c|c|l|l|l|l|l|l|l|l|}
\hline & \multicolumn{3}{|c|}{2000} & \multicolumn{2}{c|}{2001} & \multicolumn{2}{c|}{2002} & \multicolumn{2}{c|}{2015} & \multicolumn{2}{c|}{2016} \\
\hline 9. & demokracja & 218 & $\begin{array}{l}\text { środki } \\
\text { transportu }\end{array}$ & 562 & nazwiska & 267 & $\begin{array}{l}\text { środki } \\
\text { transportu }\end{array}$ & 404 & media & 275 \\
\hline 10. & zamach & 185 & władza & 541 & Al-Kaida & 246 & prawo & 370 & $\begin{array}{l}\text { Państwo } \\
\text { Islamskie }\end{array}$ & 225 \\
\hline 11. & nazwiska & 99 & prawo & 533 & gospodarka & 197 & uchodźcy & 369 & gospodarka & 178 \\
\hline 12. & - & - & media & 512 & $\begin{array}{l}\text { środki } \\
\text { transportu }\end{array}$ & 155 & $\begin{array}{l}\text { Państwo } \\
\text { Islamskie }\end{array}$ & 302 & demokracja & 176 \\
\hline 13. & - & - & nazwiska & 116 & - & - & nazwiska & 263 & nazwiska & 157 \\
\hline 14. & - & - & - & - & - & - & demokracja & 194 & uchodźcy & 112 \\
\hline 15. & - & - & - & - & - & - & media & 115 & $\begin{array}{l}\text { środki } \\
\text { transportu }\end{array}$ & 104 \\
\hline
\end{tabular}

Źródło: opracowanie własne.

Koncepty wykorzystywane w komunikatach o terroryzmie możemy zatem podzielić na stałe, czyli te, których reprezentacje odnotowano w każdym z korpusów, oraz unikalne/zmienne, uzależnione od aktualnych wydarzeń. Stałe elementy stanowią istotny kontekst dla zjawiska, przyczyniają się do budowania określonych nastrojów społecznych, podkreślają zarówno ważność podejmowanych w ich obrębie działań, jak i samych podmiotów funkcyjnych. Koncepty unikalne są istotnymi elementami analizy, ponieważ - jak widać w tabeli 3 - istnieje możliwość zaobserwowania pojawienia się danego elementu oraz jego zmienności w czasie.

W tabeli 4 przedstawione zostały kolokacje, które dominowały w poszczególnych korpusach. Zestawienie uwzględnia tylko te połączenia, które przekroczyły przyjęty próg relewancji: 15 wystąpień. Już na pierwszy rzut oka widoczna jest dysproporcja we współwystępowaniu wyrazów w korpusach przed i od 2001 r. W zbiorze tekstów z 2000 r. mamy jedynie 5 konstrukcji, które przekroczyły ustalony próg ważności, podczas gdy w każdym kolejnym roku odnotowano ich co najmniej 13. Poniższe zestawienie obrazuje, jak przez lata zmieniali się aktorzy medialnych relacji wydarzeń. W 2000 r. widoczna jest koncentracja na działaniach Władimira Putina (w Czeczeni), podczas gdy od $2001 \mathrm{r}$. dominują podmioty o charakterze islamskim (bin Laden, Państwo Islamskie). Warto także odnotować, że we wszystkich korpusach zauważalna jest korelacja z określonym obszarem geograficznym - Bliskim Wschodem (Bliski Wschód, Arabia Saudyjska, a także Izrael, Afganistan i Pakistan, które pojawiły się na listach frekwencyjnych z dużą liczbą wystąpień). 


\begin{tabular}{|c|c|c|c|c|c|c|c|c|c|}
\hline & 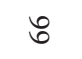 & in & 가 & $\stackrel{\infty}{m}$ & $\hat{m}$ & in & $\stackrel{\mathscr{n}}{\sim}$ & $\stackrel{\sim}{\sim}$ & $\ddot{\sim}$ \\
\hline$\frac{0}{\circ}$ & 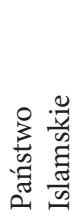 & 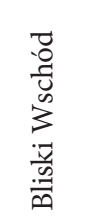 & 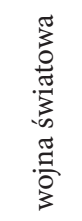 & 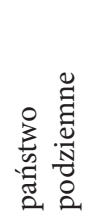 & 莺 & 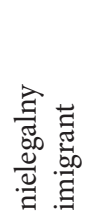 & 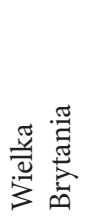 & 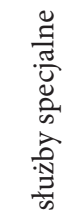 & 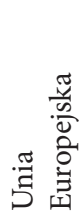 \\
\hline & $\underset{\beth}{(}$ & రె & $\vec{b}$ & $\vec{m}$ & $\stackrel{৩}{ }$ & নे & $\stackrel{\infty}{\sim}$ & $\stackrel{\sim}{\sim}$ & $\ddot{\sim}$ \\
\hline$\stackrel{\text { in }}{\frac{\gamma}{\gamma}}$ & 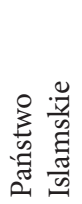 & 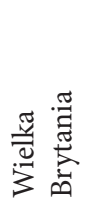 & 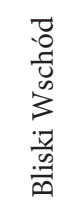 & 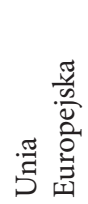 & 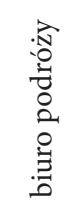 & . & 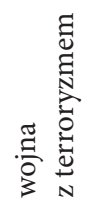 & 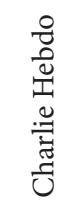 & 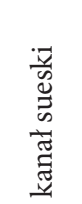 \\
\hline & n & 10 & 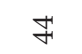 & $\stackrel{\curvearrowright}{ }$ & ঐิ & ปี & $\vec{\sim}$ & ㄱ. & $\stackrel{2}{-}$ \\
\hline ণั & 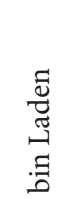 & 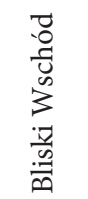 & 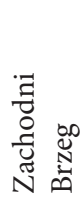 & 营 & 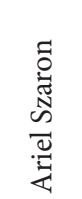 & 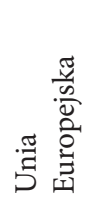 & 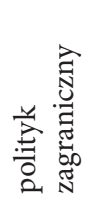 & 苟 & 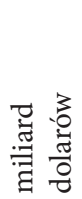 \\
\hline & $\stackrel{H}{\sim}$ & F & శે & $\stackrel{\infty}{m}$ & $m$ & $\tilde{n}$ & in & নे & $\underset{\sim}{ }$ \\
\hline চ্ণ & 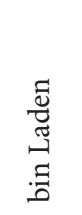 & 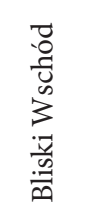 & 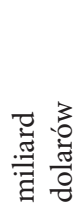 & 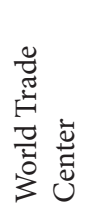 & 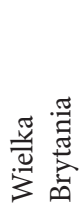 & 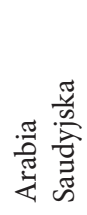 & 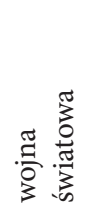 & 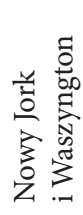 & 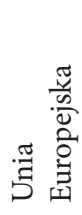 \\
\hline & $\stackrel{\mathscr{n}}{\sim}$ & $\stackrel{\mathscr{2}}{\sim}$ & $\ddot{\sim}$ & ป & $\stackrel{10}{-1}$ & 1 & I & 1 & 1 \\
\hline ষ্ণ & 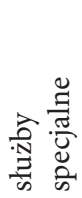 & 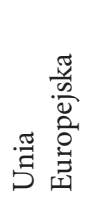 & 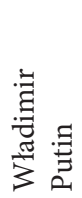 & 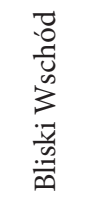 & 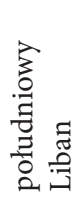 & | & 1 & 1 & I \\
\hline & $-\dot{ }$ & $\dot{\sim}$ & $\dot{m}$ & $\dot{+}$ & in & $\dot{0}^{\circ}$ & $\wedge^{\circ}$ & $\infty^{\circ}$ & $\sigma^{\circ}$ \\
\hline
\end{tabular}




\begin{tabular}{|c|c|c|c|c|c|c|c|c|c|c|c|}
\hline & $\vec{\sim}$ & $\vec{\sim}$ & $\stackrel{\infty}{\sim}$ & 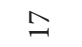 & 1 & 1 & 1 & 1 & 1 & 1 & 1 \\
\hline$\frac{0}{i}$ & 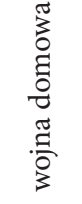 & 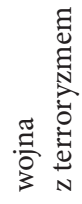 & 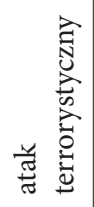 & 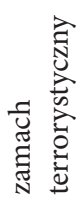 & | & I & 1 & | & 1 & | & 1 \\
\hline \multirow[b]{2}{*}{$\frac{n}{\delta}$} & $\stackrel{\infty}{\sim}$ & $\stackrel{\infty}{\sim}$ & $\stackrel{\infty}{\sim}$ & $\stackrel{\infty}{\sim}$ & $\stackrel{\infty}{\sim}$ & $\beth$ & $\underset{-1}{0}$ & 0 & $\stackrel{\Omega}{=}$ & | & 1 \\
\hline & 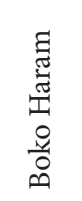 & 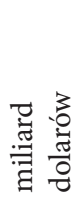 & 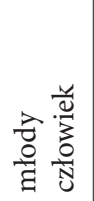 & 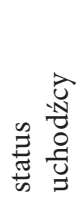 & 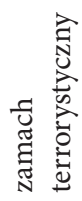 & 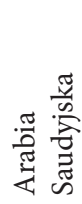 & 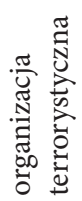 & 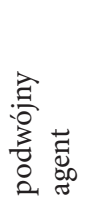 & 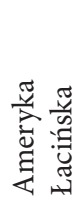 & | & | \\
\hline \multirow[b]{2}{*}{ 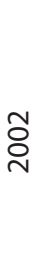 } & $\stackrel{\infty}{\sim}$ & $\stackrel{\infty}{\sim}$ & 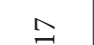 & $\stackrel{\sigma}{0}$ & 0 & $\stackrel{2}{2}$ & 1 & 1 & 1 & | & 1 \\
\hline & 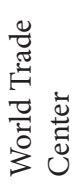 & 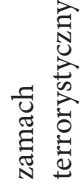 & 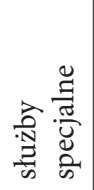 & 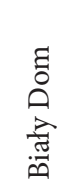 & 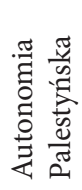 & 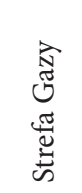 & | & | & | & | & | \\
\hline \multirow[b]{2}{*}{ চ্ণ } & $\stackrel{\mathscr{2}}{\sim}$ & $\stackrel{\llcorner}{\sim}$ & $\approx$ & 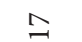 & 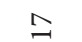 & $\stackrel{\infty}{\sim}$ & $\stackrel{2}{=}$ & $\stackrel{2}{2}$ & $\stackrel{\Omega}{=}$ & $\stackrel{2}{2}$ & $\stackrel{2}{2}$ \\
\hline & 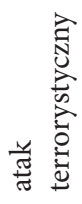 & 章 & 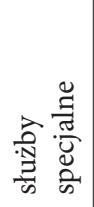 & 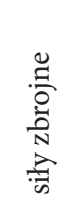 & 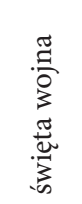 & 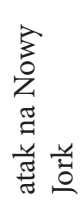 & 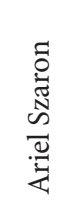 & 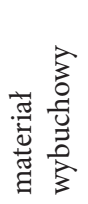 & 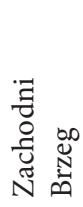 & 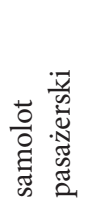 & 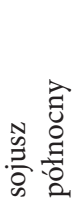 \\
\hline \multirow{3}{*}{ ஓ্ণ } & I & 1 & 1 & | & | & | & | & | & | & | & | \\
\hline & & & & & & & & & & & \\
\hline & 1 & 1 & 1 & | & 1 & 1 & | & | & | & | & | \\
\hline & $\stackrel{\circ}{\circ}$ & $\exists$ & $\stackrel{\sim}{\sim}$ & $\dot{\sim}$ & $\stackrel{\Perp}{\unlhd}$ & ம் & $\stackrel{\circ}{\circ}$ & $\doteq$ & $\stackrel{\infty}{\rightarrow}$ & $\stackrel{\circ}{2}$ & $\dot{i}$ \\
\hline
\end{tabular}


Przedstawione wyniki stanowią potwierdzenie wcześniejszych analiz — widoczna jest określona tematyzacja, wypieranie z przestrzeni medialnej jednego konfliktu przez inny (np. WTC zastąpiło konflikt palestyńsko-izraelski, który stał się jednym z głównych tematów w 2002 r.), budowanie poczucia zagrożenia (np. „wojna światowa”, „wojna z terroryzmem"), a także najbardziej charakterystyczne elementy składające się na koncept terroryzmu (np. „Państwo Islamskie”, „bin Laden”, „Bliski Wschód”).

W niniejszym badaniu przyjęto, że zamachy dokonane 11 września 2001 r. stały się wydarzeniem medialnym, w konsekwencji czego stanowią element referencyjny dla innych wydarzeń. Wśród najczęściej współwystępujących wyrazów (w zakresie analizowanego wydarzenia) odnotowano następujące konstrukcje: „World Trade Center” (2001, 2002), „atak na Nowy Jork” (2001) oraz bezpośrednio powiązane „Nowy Jork i Waszyngton" (2001).

W ramach podjętej analizy postanowiono także sprawdzić, czy i w jakich kontekstach $w$ publikacjach $\mathrm{z}$ ostatnich lat pojawiały się nawiązania do tych wydarzeń. Zamachy z 2001 r. stanowiły punkt odniesienia po atakach w Paryżu (2015): „Stany Zjednoczone przeżyły horror 11 września. Teraz padło na Francję". Zamach w Tunezji (2015) niektórzy polscy politycy określili „polskim 11 września”. Natomiast francuski dziennik „Le Monde” zamachy w Paryżu nazwał „, francuskim 11 września”. WTC było również kontekstem dla tematu asymilacji imigrantów: „Atak z 11 września 2001 r. i kolejne akty terrorystyczne wywołały falę islamofobii”. Strategia „naprawiania systemu” $i$,uszczelniania granic” wykorzystywana przez Donalda Trumpa w kampanii wyborczej też bazowała na referencjach do 11 września. Trump „wykorzystał lęki, wpisując je w narrację o niewydolności systemu i dziurawych granicach, przypominając, że niektórzy dżihadyści z 11 września przybyli do USA, mimo że byli na celowniku służb, i potem spokojnie czekali na rozkaz ataku już po wygaśnięciu wiz". Do 9/11 nawiązywano również przy okazji opisu obozów w bazie Guantanamo i na Kubie.

Niniejsza analiza pozwala w podstawowym stopniu określić tematy, strategie komunikacyjne i funkcje przywoływania zamachów z 11 września, np.:

1. Donald Trump $\rightarrow$ dyskredytacja sytemu $\rightarrow$ budowanie poczucia zagrożenia w społeczeństwie $\rightarrow$ obietnica obrony $\rightarrow$ wygranie wyborów;

2. zamachy w Paryżu $\rightarrow$ nadanie rangi wydarzeniom $\rightarrow$ budowanie poczucia zagrożenia w Europie;

3. obozy w Guantanamo $\rightarrow$ racjonalizacja podejmowanych działań $\rightarrow$ odpieranie krytyki.

Strategie te mogą stanowić punkt wyjścia do dalszych badań. Należałoby je potwierdzić podczas analizy większych zbiorów materiałów, a także uzupełnić o dodatkowe elementy.

Ostatnim etapem badania było przeanalizowanie konkordancji jednego ze słów kluczowych: „terroryzm”. W tym celu postanowiono połączyć zbiory tekstów z lat 2001-2002 oraz 2015-2016, przyjmując za wyznacznik spójność po kątem aktualnej 
(w owym czasie) sytuacji społeczno-politycznej. Analizując konteksty dla leksemu „terroryzm”, w korpusie z lat 2001-2002 można wskazać dwie strategie mówienia o terroryzmie. $Z$ jednej strony widoczne jest przedstawianie sposobów budowania strategii walki z terroryzmem, $\mathrm{z}$ drugiej - poszukiwanie przyczyn i konsekwencji zamachów (przeważnie zamachów Al-Kaidy na WTC i na Bali). Przyglądając się lewym i prawym kontekstom leksemu, dominującymi elementami są wyrazy „wojna” i „walka” oraz określenia skali zjawiska „międzynarodowy” i „światowy”. Głównym podmiotem realizującym założenia wojny z terroryzmem były Stany Zjednoczone („Albo jesteście z nami, albo z terrorystami” - G.W. Bush). Znaczna część komunikatów dotyczących tej tematyki w centrum stawiała zatem USA. Wskazywano charakter wojny, który G.W. Bush określił jako „proces długotrwały”. Dodatkowo określono sposoby zabezpieczeń stosowanych na terenie USA - po 11 września powstało chociażby „Biuro Bezpieczeństwa Kraju”. Przedstawiano też sojuszników USA w walce $\mathrm{z}$ terroryzmem oraz różnorodne przyczyny przystąpienia do koalicji, np. „Chiny przystąpiły do koalicji antyterrorystycznej nie tylko z koniunkturalnej potrzeby zachowania jak najlepszych stosunków z uczestniczącymi w niej państwami zachodnimi, lecz także ze względu na problem wewnętrzny określany mianem "separatyzmu« i usilnie podciągany pod definicję "terroryzmu " narodowy ruch niepodległościowy Ujgurów w Xinjiangu, tj. Turkiestanie Wschodnim (Chińskim)". W podobnym zakresie wspomniano działania Izraela: „wypowiedziana przez Waszyngton wojna $\mathrm{z}$ terroryzmem dostarczyła premierowi Izraela Arielowi Szaronowi wygodnego pretekstu i klimatu do pacyfikacji Zachodniego Brzegu, doprowadziła do eskalacji przemocy i na długo w przyszłość odsunęła pokojowe zakończenie tego dramatu". Co ciekawe, wśród sposobów zwalczania terroryzmu przedstawiono „udzielanie pomocy biednym krajom w rozwoju gospodarczym i powietrzne uderzenia na szkoleniowe obozy terrorystów i inne obiekty".

Oceniano również sytuację Al-Kaidy i możliwości kolejnych zamachów: „raport ONZ wskazuje, że finanse Al-Kaidy są w dobrym stanie i że nic nie wskazuje na sukcesy $\mathrm{w}$ walce $\mathrm{z}$ finansowym imperium zła. Wniosek: kto ma pieniądze - uderzy [...]. Al-Kaida znów nie ma problemu ze zbieraniem pieniędzy: spływają do niej datki, prawdopodobnie $16 \mathrm{mln}$ dol. rocznie”. Określano cele terrorystów: „zamach na Bali osiągnął jakieś cele - rozgłos, panikę, drastyczne ograniczenie ruchu turystycznego do krajów muzułmańskich, spadek inwestycji”. Jako przyczyny terroryzmu wskazywano m.in. politykę zagraniczną USA, politykę Zachodu wobec biednych krajów czy konflikt islamu z Zachodem. W tekstach został także dokładnie przedstawiony dżihad, jego interpretacja, przyczyny, cele oraz organizacje walczące w imię świętej wojny. Wychodząc poza główny kontekst (9/11), jako terrorystów wskazywano m.in. Palestyńczyków, Czeczenów, Pakistańczyków i Somalijczyków. Najczęściej przywoływane organizacje terrorystyczne to: Al-Kaida, Hezbollah, Hamas, w niewielkim stopniu nawiązywano do działalności: OWP, LFWP, Brygad Męczenników Al-Aksa, Al-Fatah, IRA, ETA, Islamskiego Dżihadu i Baader Meinhof. Wskazywano też oso- 
by uznawane za terrorystów, np. Osama bin Laden, Urlike Meinhof, Ted Kaczynski, Jaser Arafat, Mohamet Atta, Dżamal Mansur (Hamas), Salim Demoi (Hamas). Ciekawym elementem było przywołanie wypowiedzi Raula Castro, według którego „Kubańczycy mają do czynienia z terroryzmem przez ostatnie 40 lat”" (chodzi mu, rzecz jasna, o terroryzm USA).

W publikacjach z lat 2015-2016 „terroryzm” pojawiał się w wielu kontekstach, także tych wcześniej wyszczególnionych (walka i wojna z terroryzmem, przyczyny i cele terroryzmu). Nie zostały one jednak odnotowane w stopniu pozwalającym określić je jako dominujące. Komunikaty tworzone były wokół PI (co można było zaobserwować już na poziomie kolokacji - tabela 4): przyczyn i metod działania, sposobów organizacji grupy, dokonanych zamachów i osiąganych celach na Bliskim Wschodzie. Przedstawiono również zasady rekrutacji PI w Europie i ich konsekwencje: „Obecnie sporo ludzi młodych z Europy przechodzi na islam i jedzie do Iraku i Syrii, by walczyć w szeregach tzw. Państwa Islamskiego. Tam znajdują spełnienie i często śmierć. Utwierdzamy ich w tym myśleniu, gloryfikując wojennych bohaterów”. W tekstach zamieszczono także definicję: „nowego terroryzmu z nożem, z siekierą, za kierownicą ciężarówki (znaleziono już nawet na tę kategorię zamachów, do których po czasie przyznaje się np. ISIS, określenia w psychiatrycznym żargonie: pseudocommando, soloterroryzm)". Za istotne konteksty, w których pojawiał się „terroryzm”, należy uznać wojnę w Syrii oraz kryzys imigracyjny w Europie. Koncepty te są z sobą bezpośrednio powiązane, co widać w publikacjach wskazujących kryzys jako konsekwencję wojny. Koncept „uchodźców” konstruowany był zarówno za pomocą kontekstów pozytywnych, w których zarysowane jest rozróżnienie między islamistą a muzułmaninem, np. „Prezydent Francji ogłasza, że jego kraj przyjmie 30 tys. przybyszów. Rozumie bowiem, że zabici w paryskim zamachu i uchodźcy - w większości muzułmanie - to ofiary tej samej zbrodniczej sekty. Że wrogość Europejczyków do muzułmanów w ogólności oznacza więcej rekrutów dla dżihadu, czyli odgrywanie scenariusza napisanego przez tzw. Państwo Islamskie", jak i negatywnych, w których takie rozróżnienie nie funkcjonuje. Komentatorzy uogólniają problem, stawiając znak równości między imigrantami a terrorystami, przyjmując atrybut religii i pochodzenia jako podstawowy element identyfikacji terrorystów: „Dziś z kolei głównym nurtem nowoczesnej polityki stała się polityka strachu kryjąca się we wspomnianym »wszyscy terroryści to imigranci«, Orbán stwierdził: każdy terrorysta jest imigrantem".

W przytoczonych przykładach można zauważyć, że posługiwanie się danym konceptem stało się elementem strategii politycznej. W publikacjach $z$ lat 2015-2016 poruszono wiele kwestii dotyczących terroryzmu, co przełożyło się na mnogość przywoływanych organizacji (nawiązywano m.in. do Państwa Islamskiego, Czerwonych Brygad, Tamilskich Tygrysów, Al-Kaidy w Maghrebie, Hamasu, Hezbollahu, Al-Szabab, Syryjskiego Ruchu Islamski Świt, Jaish al Mujahireen wal Ansar, Ansar al-Din, Szarych Wilków, ETA, LFWP, Kurdów) i sylwetek terrorystów (Chalid Me- 
szal - Hamas, Anders Breivik, Baszar Asad, Hassan Nasrallah - Hezbollah, Ajman al-Zawahiri, Osama bin Laden, Saïd i Chérif Kouachi - PI, Timothy MacVeigh, Mohamed Lahoualej Bouhlel - PI, Yassin Salhieg - PI, Najim Laachraoui - PI, Abu Bakr al-Baghdadiego - PI).

Na podstawie otrzymanych kolokacji i jakościowej analizy kontekstów można wnioskować, że w latach 2001-2002 niejako „twarzą terrorystów” był Osama bin Laden, a komunikaty koncentrowały się w mniejszym lub większym stopniu wokół jego działalności. W aktualnych tekstach podejmowana tematyka jest bardzo szeroka, poruszanych jest wiele kwestii zarówno bieżących, jak i historycznych. Mnogość zamachów terrorystycznych w Europie, a w konsekwencji komunikatów ich dotyczących, przywoływanie wielu nazwisk, nazw organizacji itp. przyczynia się do wielu uogólnień w procesie konstrukcji obrazu terrorysty/terroryzmu. Na podstawie przeanalizowanych tekstów (2015-2016) trudno określić, kto w dzisiejszych czasach jest terrorystą "numer jeden” (w tekstach z lat 2016-2016 odnotowano tylko dwa nawiązania do lidera PI - Abu Bakr al-Baghdadiego), jednak bez problemu możemy wskazać atrybuty terrorystów — religię i przynależność do ISIS.

\section{Zakończenie}

Przyjmując założenia przedstawione w teoretycznej części niniejszego artykułu, założono, że szeroko pojęte media stanowią główne źródło informacji na temat zjawisk, z którymi nie mamy bezpośredniego kontaktu. Uznano zatem, że sposób konstruowania obrazu terroryzmu przez media stanowi istotny element konstrukcji zjawiska przez odbiorców. Głównym celem proponowanego badania było zaobserwowanie, jakie koncepty wykorzystywane są przez media do mówienia o terroryzmie, określenie dominujących tematów, odnalezienie wydarzeń medialnych stanowiących referencję dla innych oraz określenie pola semantycznego wyrazu „terroryzm”. W ramach badań pilotażowych zastosowano wszystkie opisane procedury badawcze, dokonano analiz porównawczych oraz przedstawiono wyniki cząstkowe. Pozwoliło to na określenie adekwatności dobranej metody i udoskonalenie procesu przed badaniem właściwym.

Na poziomie kwalifikacji materiałów do analizy i konstrukcji korpusów zauważono, że liczba komunikatów dotyczących terroryzmu w 2000 r. była znacznie mniejsza niż w latach późniejszych. Publikacje z tego roku koncentrowały się wokół dwóch tematów: wojny w Czeczeni i konfliktu palestyńsko-izraelskiego. W publikacjach z 2001 r. dominowały z kolei referencje do zamachów z 11 września 2001 r., podczas gdy w 2002 r. odnoszono się zarówno do WTC, jak i działań w Palestynie. Warto zauważyć, że zamachy 9/11 wyparły w $2001 \mathrm{r}$. komunikaty dotyczące np. konfliktu w Palestynie, pomimo wzmożonych działań wojskowych w tamtym okresie. Można 
zatem przyjąć, że długotrwałe konflikty stanowią swoistego rodzaju „temat dyżurny”, do którego media zawsze mogą wrócić. Oczywiście założenie to wymaga potwierdzenia w dalszych etapach badania, do których zostaną włączone teksty z lat 2003-2005 (Druga Intifiada, zamachy w Madrycie).

Zwrócono także uwagę, że przed zamachami z 11 września w tekstach dotyczących terroryzmu media $\mathrm{w}$ niewielkim stopniu odnosiły się do religii (na listach frekwencyjnych nie odnotowano leksemów stanowiących reprezentację tej kategorii). Leksem „islam” znalazł się natomiast wśród 30 najczęściej występujących rzeczowników w korpusach z lat późniejszych. Na tej podstawie możemy wnioskować, że koncept „religia” jest bezpośrednio związany z terroryzmem od $2001 \mathrm{r}$.

$\mathrm{Na}$ podstawie zestawień ilościowych możliwe było wskazanie tematów, które stały się kontekstem dla terroryzmu, np. konkretnych zamachów czy podejmowanych działań politycznych. Dodatkowo udało się wskazać stałe koncepty wykorzystywane przez media do mówienia o terroryzmie, m.in. takie jak „wojna”, „polityka”. Co ciekawe, elementy te stanowią podstawowe kategorie w każdym z korpusów, a co za tym idzie - nie są zmienne w zależności od aktualnych wydarzeń. Wyróżniono także koncepty unikalne, uzależnione od sytuacji społeczno-politycznej, np. „uchodźcy”.

Wykorzystanie list frekwencyjnych umożliwiło wskazanie krajów, które były przywoływane w kontekście tematyki terroryzmu. W publikacjach wskazywano funkcje i rolę poszczególnych państw, np. USA: walka z terroryzmem, zamach na WTC; Turcja: zamachy terrorystyczne, przyjmowanie uchodźców; Pakistan: obozy szkoleniowe terrorystów itd. W tekstach odnaleziono próby definicji terroryzmu i zaobserwowano dyferencjacje między terroryzmem z lat wcześniejszych a „nowym terroryzmem”. Zidentyfikowano głównych aktorów dyskursu o terroryzmie: Al-Kaidę i Państwo Islamskie, które w konkretnych przedziałach czasowych stanowiły główny element referencyjny. Na podstawie otrzymanych wyników można wnioskować, że PI i jego działalność w komunikacji medialnej zastąpiło Al-Kaidę. Obserwacja ta może stanowić istotną perspektywę w badaniu właściwym, skupiając uwagę badacza na identyfikacji konkretnych wydarzeń (w tym określenie czasu odnotowanej zmiany).

W niniejszym badaniu przyjęto, że zamachy dokonane przez Al-Kaidę 11 września w USA stały się wydarzeniem medialnym, uległy tradycjonalizacji i stały się częścią kultury, stanowiąc element referencyjny dla innych tematów. Przeanalizowano zatem konteksty nawiązań do WTC oraz postanowiono określić funkcje takich zabiegów. Wyszczególniono kilka podstawowych strategii komunikacyjnych funkcjonujących w mediach, np. zamachy $9 / 11$ jako legitymizacja działań, budowanie poczucia zagrożenia, dyskredytacja przeciwnika, podkreślenie znaczenia wydarzenia. Lista wymaga uzupełnienia, jednak stanowi punkt wyjścia i kierunkuje dalsze analizy.

Jednym $z$ ważnych celów badania była próba wskazania wydarzenia, któremu media nadały wysoką rangę, przez co stało się ono wydarzeniem medialnym. Po przeprowadzeniu analizy publikacji z lat 2015-2016 bardzo ostrożnie można wskazywać na koncept „wojny w Syrii” z całym zapleczem komunikatów bezpośrednio i pośred- 
nio do niej nawiązujących oraz szerokim wachlarzem tematów skorelowanych. Niemniej jednak sposoby konstruowania syryjskiej wojny w mediach wymagają wnikliwej analizy na znacznie obszerniejszym materiale badawczym, co jest możliwe do zrealizowania w badaniu właściwym.

Przeprowadzone badanie pilotażowe umożliwiło sprawdzenie planowanych procedur badawczych na mniejszym zbiorze wyjściowym. Pomimo zrealizowanych celów dopracowania wymaga kilka elementów, które ułatwią pracę na dużym zbiorze danych i przyczynią się do ustrukturyzowania wyników, np. precyzyjniejszy dobór próby, zorientowany na teksty ściśle powiązane z terroryzmem, tematyczna klasyfikacja każdego materiału.

\section{The media image of terrorism — a study design and results of pilot studies}

Summary

The article presents a concept of a study focusing on the mediatisation of terrorism. The author seeks to capture how the media construct (define) terrorism; she looks the selection of events which the media consider to be acts of terror as well as ways of hierarchising them. On this basis she attempts to reconstruct the media image of terrorism and terrorists. Her analysis begins with Niklas Luhmann's concept of mass media, according to which in contemporary mediatised societies the media are the basic source of information about the world. They represent and construct particularly those areas of life we cannot reach directly. In the study the author used techniques and methods applied in corpus research and making it possible to analyse key words appearing in media materials concerning terrorism as well as lexemes used to describe the notions of "terrorist" and "terrorism". 